by Birger Schmitz, Victoriano Pujalte ${ }^{2}$,Eustoquio Molina ${ }^{3}$, Simonetta Monechi ${ }^{4}$, Xabier Orue-Etxebarria ${ }^{2}$, Robert P. Speijer ${ }^{5}$, Laia Alegret ${ }^{3}$, Estibaliz Apellaniz ${ }^{2}$, Ignacio Arenillas ${ }^{3}$, Marie-Pierre Aubry ${ }^{6}$, Juan-Ignacio Baceta ${ }^{2}$, William A. Berggren ${ }^{7}$, Gilen Bernaola ${ }^{8}$, Fernando Caballero ${ }^{2}$, Anne Clemmensen ${ }^{9}$, Jaume Dinarès-Turell ${ }^{10}$, Christian Dupuis ${ }^{11}$, Claus Heilmann-Clausen ${ }^{9}$, Asier Hilario Orús ${ }^{12}$, Robert Knox ${ }^{13}$, Maite Martín-Rubio ${ }^{8}$, Silvia Ortiz, Aitor Payros ${ }^{2}$, Maria Rose Petrizzo ${ }^{14}$, Katharina von Salis ${ }^{15}$, Jorinde Sprong ${ }^{5}$, Etienne Steurbaut ${ }^{16}$ and Erik Thomsen ${ }^{9}$

\title{
The Global Stratotype Sections and Points for the bases of the Selandian (Middle Paleocene) and Thanetian (Upper Paleocene) stages at Zumaia,
}

\section{Spain}

1 Department of Geology, Lund University, SE-22362 Lund, Sweden. Email: birger.schmitz@geol.lu.se

2 Department of Stratigraphy and Paleontology, University of the Basque Country, E-48080 Bilbao, Spain.

3 Department of Earth Sciences, Zaragoza University, E-50009 Zaragoza, Spain.

4 Department of Earth Sciences, Florence University, I-50121 Florence, Italy.

5 Department of Earth and Environmental Sciences, K.U. Leuven, B-3001 Leuven, Belgium.

6 Department of Geology, Rutgers University, Piscataway, NJ 08854, USA.

7 Department of Geology and Geophysics, Woods Hole Oceanographic Institution, Woods Hole, MA 02543, USA.

8 Department of Mining and Metallurgic Engineering and Material Sciences, University of the Basque Country, E-48901 Barakaldo, Spain.

9 Department of Earth Sciences, Århus University, DK-8000 Århus C, Denmark.

${ }^{10}$ Instituto Nazionale di Geofisica e Vulcanologia, Via di Vigna Murata 605, I-00142 Rome, Italy.

${ }^{11}$ Laboratoire de Géologie Fondamentale et Appliquée, Faculté Polytechnique de Mons, B-7000 Mons, Belgium.

${ }^{12}$ Eguzkialde 13, E-20271 Irura, Gipuzkoa, Spain.

${ }^{13}$ British Geological Survey, Kingsley Durham Centre, Keyworth, Nottingham NG12 5GG, United Kingdom.

${ }^{14}$ Department of Earth Sciences, Milano University, I-20133 Milano, Italy.

${ }^{15}$ Via Maistra 9, CH-7513 Silvaplana, Switzerland.

${ }^{16}$ Department of Paleontology, Royal Belgian Institute of Natural Sciences, B-1000 Brussels, Belgium.

The global stratotype sections and points for the bases of the Selandian (Middle Paleocene) and Thanetian (Upper Paleocene) stages have been defined in the coastal cliff along the Itzurun Beach at the town of Zumaia in the Basque Country, northern Spain. In the hemipelagic section exposed at Zumaia the base of the Selandian Stage has been placed at the base of the Itzurun Formation, ca. $49 \mathrm{~m}$ above the Cretaceous/ Paleogene boundary. At the base of the Selandian, marls replace the succession of Danian red limestone and limestone-marl couplets. The best marine, global correlation criterion for the basal Selandian is the second radiation of the important calcareous nannofossil group, the fasciculiths. Species such as Fasciculithus ulii, F. billii, F. janii, F. involutus, F. pileatus and F. tympaniformis have their first appearance in the interval from a few decimetres below up to $1.1 \mathrm{~m}$ above the base of the Selandian. The marker species for nannofossil Zone NP5, F. tympaniformis, first occurs 1.1 m above the base. Excellent cyclostratigraphy and magnetostratigraphy in the section creates further correlation potential, with the base of the Selandian occuring 30 precession cycles (630 kyr) above the top of magnetochron C27n. Profound changes in sedimentology related to a major sea-level fall characterize the Danian-Selandian transition in sections along the margins of the North Atlantic.

The base of the Thanetian Stage is placed in the same section ca. $78 \mathrm{~m}$ above the Cretaceous/Paleogene boundary. It is defined at a level $2.8 \mathrm{~m}$ or eight precession cycles above the base of the core of the distinct clay-rich 
interval associated with the Mid-Paleocene Biotic Event, and it corresponds to the base of magnetochron C26n in the section. The base of the Thanetian is not associated with any significant change in marine micro-fauna or flora. The calcareous nannofossil Zone NP6, marked by the first occurrence of Heliolithus kleinpelli starts ca. $6.5 \mathrm{~m}$ below the base of the Thanetian. The definitions of the global stratotype points for the bases of the Selandian and Thanetian stages are in good agreements with the definitions in the historical stratotype sections in Denmark and England, respectively.

\section{Paleocene GSSPs - introduction and background}

In 1993 the Paleocene Working Group was commissioned by the International Subcommission on Paleogene Stratigraphy to define global stratotype sections and points for the bases of the Selandian and Thanetian stages (Schmitz 1994). A stage represents the basic chronostratigraphic unit in the global Geological Timescale, and the base of each stage is defined by a Global Boundary Stratotype Section and Point (GSSP) in an appropriate, continuous marine section. The GSSP represents a point both in ancient time and in the rock record, and its definition facilitates communication among earth scientists. After fourteen years of research and discussions the members of the Paleocene Working Group agreed unanimously in June 2007 on forwarding the proposal that the bases of the Selandian and Thanetian stages should be placed in the Zumaia section at the Spanish coast of the Bay of Biscaye. Following approvals in 2008 by the International Subcommission on Paleogene Stratigraphy and the International Commission on Stratigraphy this suggestion was accepted and formally ratified by the International Union of Geological Sciences on September 23, 2008. This paper gives a summary and background of the research and considerations underlying this decision.

\section{The Selandian and Thanetian stages - historical background}

The division of the Paleocene Series into three stages, Danian, Selandian and Thanetian, was decided by the International Subcommission on Paleogene Stratigraphy at the 1989 International Geological Congress in Washington (Jenkins and Luterbacher 1992). The base of the lower stage, the Danian, coincides with the Cretaceous/ Paleogene boundary which has been formally defined in the El Kef section in Tunisia at the base of the iridium-rich clay layer that formed after a major asteroid or comet impact on Earth (Molina et al. 2006, 2009).

The second Paleocene stage, the Selandian, was originally described in Denmark by Rosenkrantz (1924) and consists of fossiliferous glauconitic marls (Lellinge Greensand and Kerteminde Marl) overlain by unfossiliferous grey clay (now subdivided into Æbelø Formation, Holmehus Formation and Østerrende Clay) (Fig. 1). The succession unconformably overlies Danian chalks and limestones and contains clasts derived from these units in its basal part (Perch-Nielsen and Hansen 1981; Berggren 1994). In the original

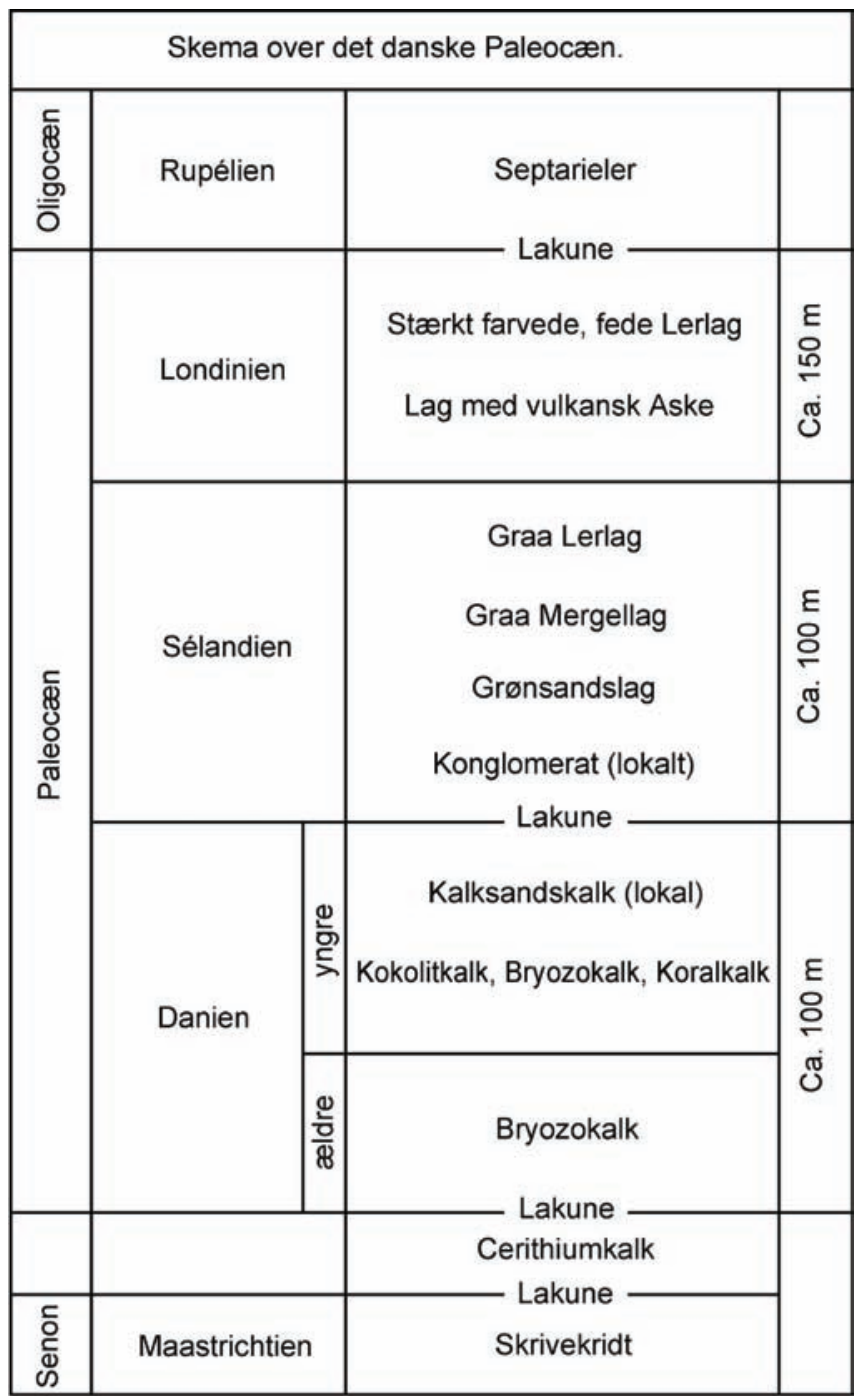

Figure 1. Stratigraphic scheme for the Paleocene in Denmark by Rosenkrantz (1924). This is the first use of the regional stage "Sélandien".

type area the Selandian deposits are overlain by the earliest Eocene Ølst Formation and Fur Formation ("Mo Clay"), containing the numerous, well-known "numbered" ash layers (Pedersen and Surlyk 1983). In the North Sea region the Danian/Selandian boundary reflects the end of ca. 40 million years of continuous deposition of openmarine carbonates, and represents a major change in the tectonic evolution of the northeastern Atlantic (Ziegler 1990; Berggren et al. 1995; Clemmensen and Thomsen 2005; Nielsen et al. 2007). It is notable that until the middle of the 20th century the Cretaceous/ Paleogene boundary was still often placed at the top of the Danian limestone (see review in Berggren 1971). Based on Danish outcrop sections, the Danian/Selandian boundary has traditionally been placed near the planktonic foraminifera zones P2/P3 boundary (e.g., Berggren et al. 1995), but this reflects the existence of major unconformities at the limestone/greensand boundary. Later studies of more continuous drill cores in the region indicate a more gradual lithological change and a significantly younger age, in the middle of the Zone P3 and close to the calcareous nannofossil zones NP4/NP5 boundary (Thomsen and Heilmann-Clausen 1985; Thomsen 1994; Clemmensen and Thomsen 2005). 
The Thanetian Stage concept was first used by Renevier (1873) who included the Thanet Sands with Cyprina morris and the Woolwich and Reading Beds with Cyrena cuneiformis. Its meaning was subsequently narrowed by Dollfus (1880), who included only the Thanet Sands, the original type-strata on the Isle of Thanet in southeast England. Since 1880 the term Thanetian has consistently been used with the restricted meaning of Dollfus (Bignot et al. 1997). Intensive bio- and magnetostratigraphic studies and sequence stratigraphic analysis on outcrops and wells in the type area have led to a detailed understanding of the extent of the Thanetian with regard to the magnetobiochronologic time scale (Aubry 1994). The historical Thanetian strata span calcareous nannofossil zones NP6-NP9 of Martini (1971), polarity chrons C26n-C24r (Ali and Jolley 1996) and dinoflagellate zones Viborg 4 and 5 of Heilmann-Clausen (1985, 1994). Studies of drill cores show that the base of the historical Thanetian Stage lies in the upper part of Zone NP6 and close to the base of Chron C26n (Hine 1994; Knox 1994a). A major increase in the abundance of the dinoflagellate Alisocysta gippingensis is considered a useful event for recognizing the base of the Thanetian within the North Sea Basin, while the last occurrence of Palaeoperidinium pyrophorum and Palaeocystodinium australinum/ bulliforme are late Selandian events that are useful for interregional correlations (Heilmann-Clausen 2007).

\section{The Zumaia section - geography and physical geology}

The Zumaia section is part of an essentially continuous lower Santonian to lower Eocene sea-cliff outcropping along the coast of the Gipuzkoa province halfway between Bilbao and San Sebastian (Fig. 2). The Paleocene part of the section is represented
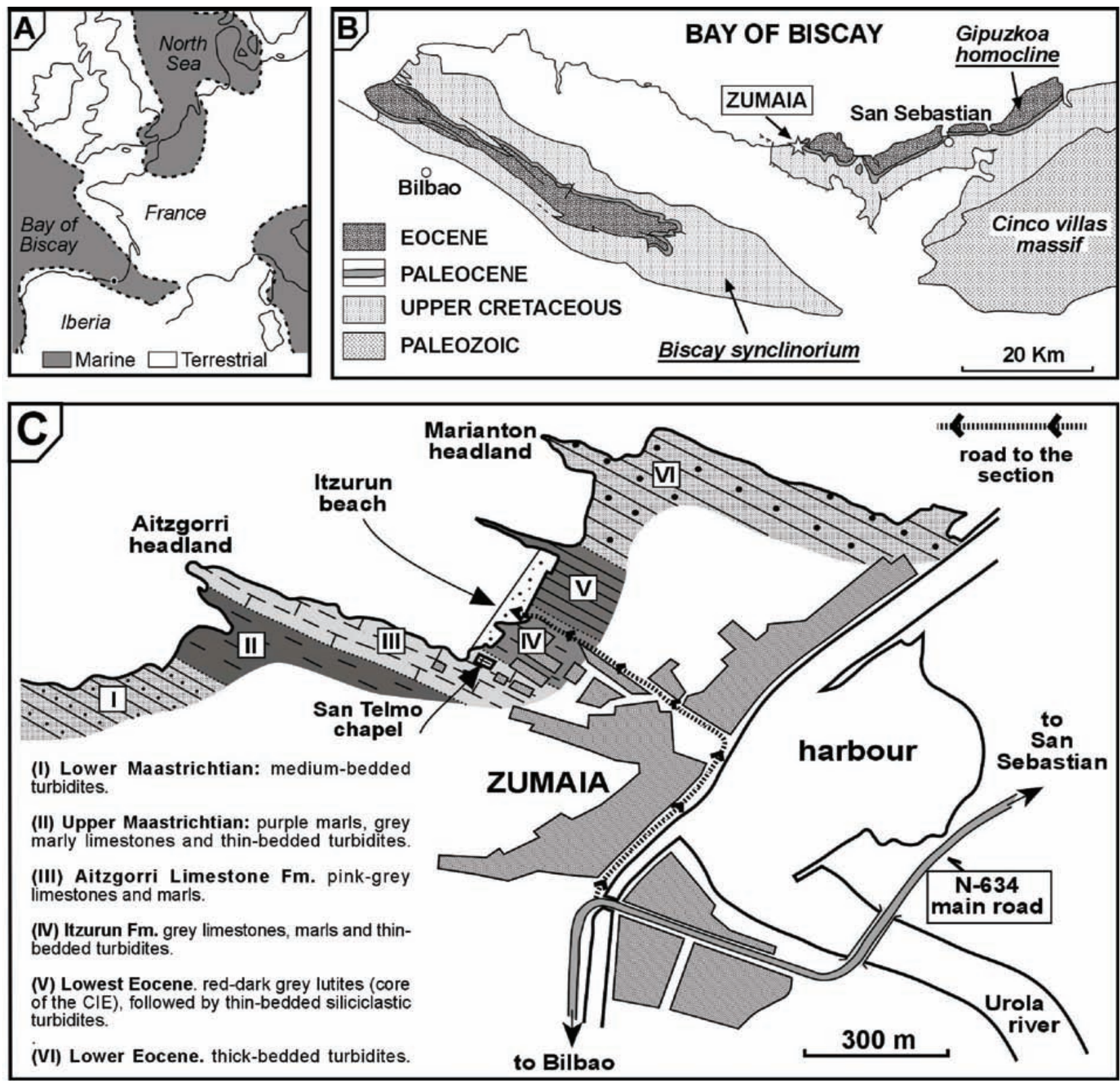

Figure 2. (A) Generalized early Paleogene paleogeographic map of Western Europe; (B) Simplified geologic map of the study region, showing the most important Paleocene outcrops and the location of the Zumaia beach section; (C) Geologic map of the Upper Cretaceous - Lower Paleogene outcrops in the Zumaia area. 
by a ca. $165 \mathrm{~m}$ thick essentially complete record exposed along the main beach, the Itzurun Beach, of the coastal town Zumaia (latitude/ longitude $43^{\circ} 17^{\prime} 57.1^{\prime \prime} \mathrm{N} / 2^{\circ} 15^{\prime} 39.6^{\prime \prime} \mathrm{W}$; Spanish spelling is "Zumaya", but we use here the original Basque name). The bulk of the Paleocene is represented by rhythmic alternations of hemipelagic deposits in the form of indurated limestones, marly limestones and marlstones, plus numerous intercalations of thin-bedded turbidites (Pujalte et al. 1995; Baceta 1996; Pujalte et al. 1998a). The distinct stratigraphic cyclicity has been attributed to orbital forcing (Ten Kate and Sprenger 1993; Baceta 1996; Dinarès-Turell et al. 2002, 2003, 2007, 2010). The sediments were deposited at an estimated water depth of $1000 \mathrm{~m}$ corresponding to a middle to lower bathyal setting (Pujalte et al. 1998a; Arenillas et al. 2008). Sedimentation was hemipelagic with a terrestrial component supplied axially from the emerging proto-Pyrenees and marginally from shallow carbonate platforms to the south and north (Fig. 3). Other nearby sections such as at Ermua, ca. $25 \mathrm{~km}$ to the southwest, provide records of the sedimentation in the base of slope apron fringing the southern carbonate platform (Fig. 3), and contain a higher fraction of terrigenous matter, and also carbonate slump deposits and calciturbidites (Baceta 1996; Pujalte et al. 1998a; Schmitz et al. 2001). Due to the superb quality of its exposure, the Zumaia section already attracted the attention of pioneer workers in the region (e.g., Gómez de Llarena 1946). The Zumaia section was also subject to important ichnological studies, e.g. the classic study of turbidites and their associated pre- and postdepositional trace fossils by Seilacher (1962). It was later the subject of general studies of planktonic foraminifera (Hillebrandt 1965), calcareous nannofossils (Kapellos 1974; Van Vliet 1982), depositional setting (Van Vliet 1982) or sequence stratigraphy (Baceta 1996; Pujalte et al. 1998a,b), to mention a few. Several papers have focused on the Cretaceous/ Paleogene and the Paleocene/Eocene boundaries, including Alvarez et al. (1982), Wiedman (1986), Smit and Ten Kate (1982), Canudo and Molina (1992), Gorostidi (1993), Ward and Kennedy (1993),
Canudo et al. (1995), Ortiz (1995), Kuhnt and Kaminski (1997), Schmitz et al. (1997a), Molina et al. (1998, 1999), Knox (1998), Apellaniz (1998), Arenillas et al. (1998, 2004), Arz et al. (1999), Adatte et al. (2000), Arenillas and Molina (2000), Bernaola (2002), Orue-Etxebarria et al. (2004) and Caballero (2007). These two important boundaries, the base and the top of the Paleocene, are excellently exposed and preserved in the section along the Itzurun Beach cliffs. Zumaia was in fact the main challenger for hosting the GSSPs for both the Cretaceous/Paleogene and the Paleocene/Eocene boundaries, that were eventually placed at El Kef (Tunisia) and Dababiya (Egypt), respectively (Molina et al. 2006, 2009; Aubry et al. 2007).

\section{The GSSP for the Selandian - position, stratigraphy and completeness}

\section{Precise position}

The base of the Selandian Stage, the second or middle stage in the Paleocene Series, is placed at the base of the Itzurun Formation in the section at Itzurun Beach in Zumaia (Arenillas et al. 2008; Bernaola et al. 2009). The stratotype point for the basal Selandian is equivalent to the base of the marls overlying the uppermost limestone bed of the ca. 10 meters of limestone-marl couplets in the upper part of the Aitzgorri Limestone Formation (Figs. 4-9). The base of the Selandian is thus ca. 49 meters above the Cretaceous/Paleogene boundary, following the log of Dinarès-Turell et al. (2003).

\section{Lithostratigraphy}

The Aitzgorri Limestone Formation is dominantly made up of reddish limestone, with varying amounts of rhythmically appearing marl intercalations, whereas the dominant lithology in the lower part

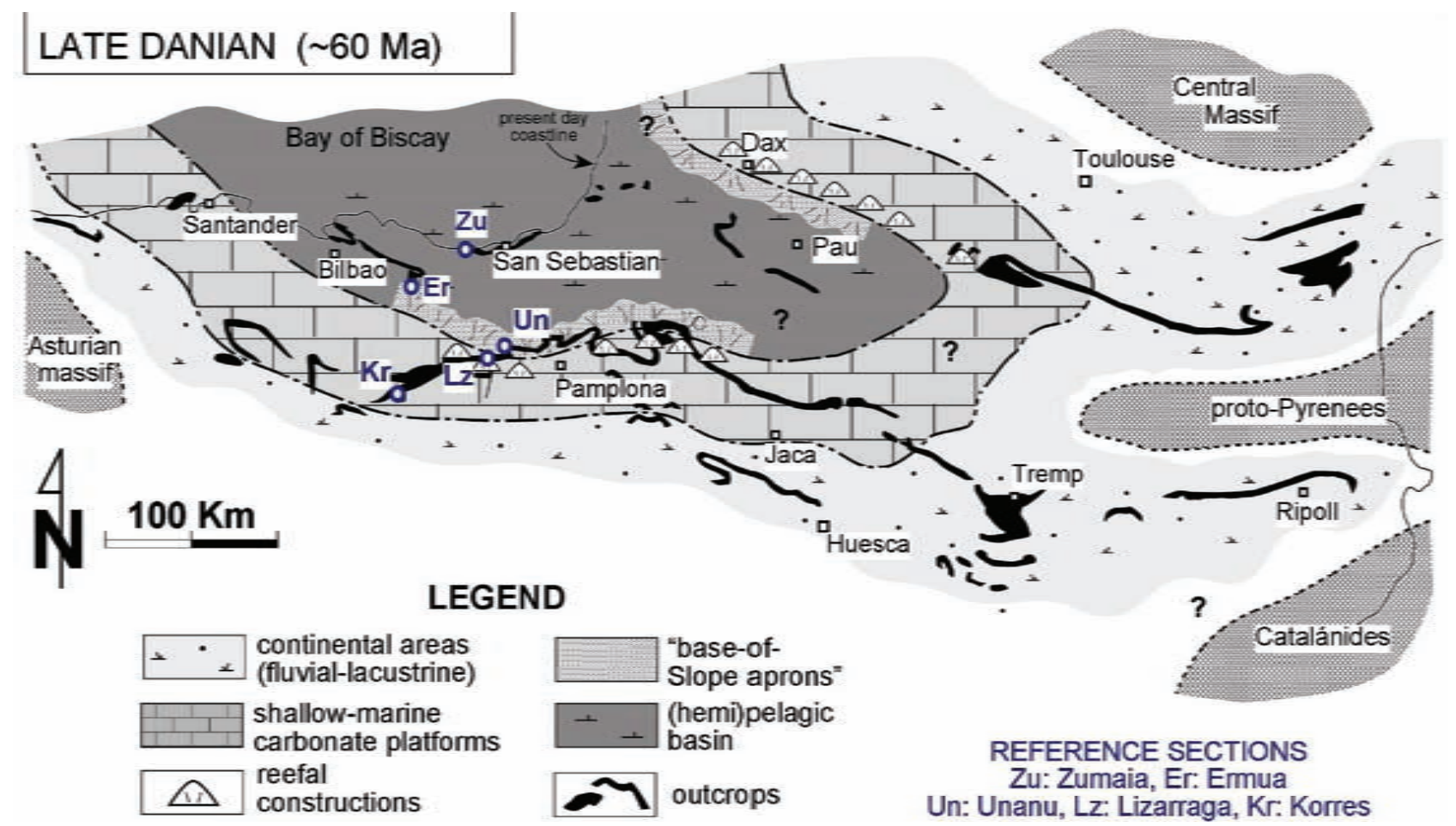

Figure 3. Late Danian paleogeography of the Pyrenean domain with reference sections and localities. From Baceta et al. (2004). 

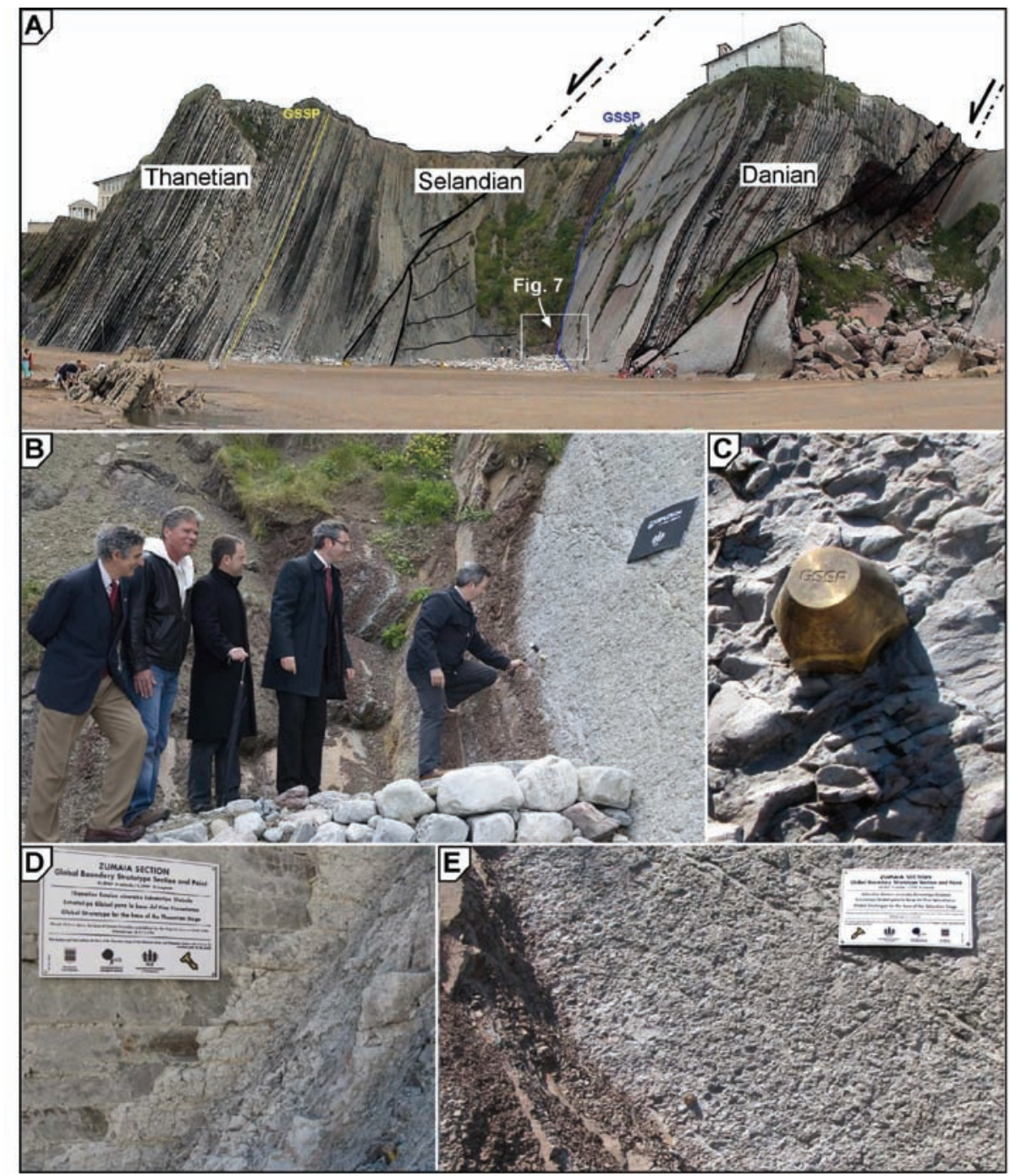

Figure 4. (A) The upper Danian to lower Thanetian section in the cliffs at Itzurun Beach. The bases of the Selandian and Thanetian stages are marked by blue and yellow lines, respectively. The white square is enlarged in Fig. 7. (B) and (C) The GSSP "golden spikes" were placed at the bases of the Selandian and Thanetian on May 6, 2010. (D) The base of the Thanetian Stage. (E) The base of the Selandian Stage.

of the Itzurun Formation is greyish marlstones: however, color and lithology vary throughout the formation. The Danian/Selandian boundary is defined at the abrupt lithological change between the two formations (Figs. 4-9). In the upper part of the Aitzgorri Limestone Formation, largely of pink-reddish colors, the lower "crowded" and the upper "stratified" members can be distinguished (Baceta et al. 2006). The crowded member is $7 \mathrm{~m}$ thick and consists of limestones amalgamated or with very thin marly interbeds. The stratified member, $9 \mathrm{~m}$ thick, takes its name from the well defined rhythmic bedding and the clearly distinguishable marl-limestone alternations. Some of the best examples of so called bundles representing the ca. $100 \mathrm{kyr}$ eccentricity cycles can be identified in this part of the section (DinarèsTurell et al. 2003). The lower ca. $15 \mathrm{~m}$ of the overlying Itzurun Formation exhibits higher vertical variations in both the relative proportions of hemipelagic sediments and the frequency of turbidite intercalations. Dark to light grey colors dominate through the Itzurun Formation, but the basal $2.85 \mathrm{~m}$ interval of marls and marlstones has a characteristic red color (Fig. 7) (Schmitz et al. 1998). The Aitzgorri Limestone Formation has previously been referred to as the Danian
Limestone Formation (e.g., Apellaniz et al. 1983), however, according to the guidelines of the International Commission on Stratigraphy, the name of formal stratigraphic units (i.e., group, formation) should consist of an appropriate geographic name combined with an appropriate term indicating the kind and rank of the unit (Bernaola et al. 2009). Geographic names should be derived from permanent natural or artificial features near the stratigraphic feature. If a lithologic term is added to the name of a lithostratigraphic unit it should be a simple and generally accepted term that indicates the predominant lithology of the unit.

Careful examination of the Aitzgorri Limestone/Itzurun formational boundary at the Itzurun Beach section and in two additional sections in Zumaia located close to the N634 road to San Sebastian, on the eastern bank of the Urola river mouth (Fig. 2), indicates that this transition is clearly conformable. There is no evidence for any erosional gap or omission surface at this level. Throughout the Danian/ Selandian boundary interval limestone-marl transitions are always gradual and no evidence for hardgrounds or stratigraphic diastems has been identified in the beach cliff section or in other sections around Zumaia. The presence of turbidites (only five levels observed) does not involve erosion, since they mostly occur as thin or very thin plane layers $(0.5-5 \mathrm{~cm})$ with Tc-e Bouma internal sequences and bases lacking evidence of channelling or erosional truncation. Trace fossils, common through the whole interval, mainly Zoophycos, Planolites and Chondrites, show no evidence of truncation. Precise bed-by-bed correlation is possible across the whole basin floor domain, even between sections $100 \mathrm{~km}$ apart, such as Sopelana and Hendaia, further indicating lack of major unconformities (Baceta 1996; Pujalte et al. 1998a).

\section{Calcareous nannofossils}

The expanded nature of the Danian-Selandian transition at Zumaia is evident from the gradual sequence of first appearances of the typical calcareous nannofossils of the period (Fig. 8, from Bernaola et al. 2009). For example, the stratigraphic distance between the first diversification of Fasciculithus and the first occurrence (FO) (used in the same sense as lowest occurrence) of Fasciculithus tympaniformis at Zumaia is about $11 \mathrm{~m}$. This is ca. $6 \mathrm{~m}$ thicker than in the section at Qreiya in the Eastern Desert of Egypt (Monechi and Reale 2007; Rodríguez and Aubry 2007). The expanded nature of the record at Zumaia is also apparent by the thickness, $13.6 \mathrm{~m}$, between the FO of Sphenolithus primus to the FO of F. tympaniformis. The base of nannofossil Zone NP5 according to the scheme of Martini (1971) is defined by the FO of F. tympaniformis, which is located $1.1 \mathrm{~m}$ above the base of the Itzurun Formation, i.e. the base of the 

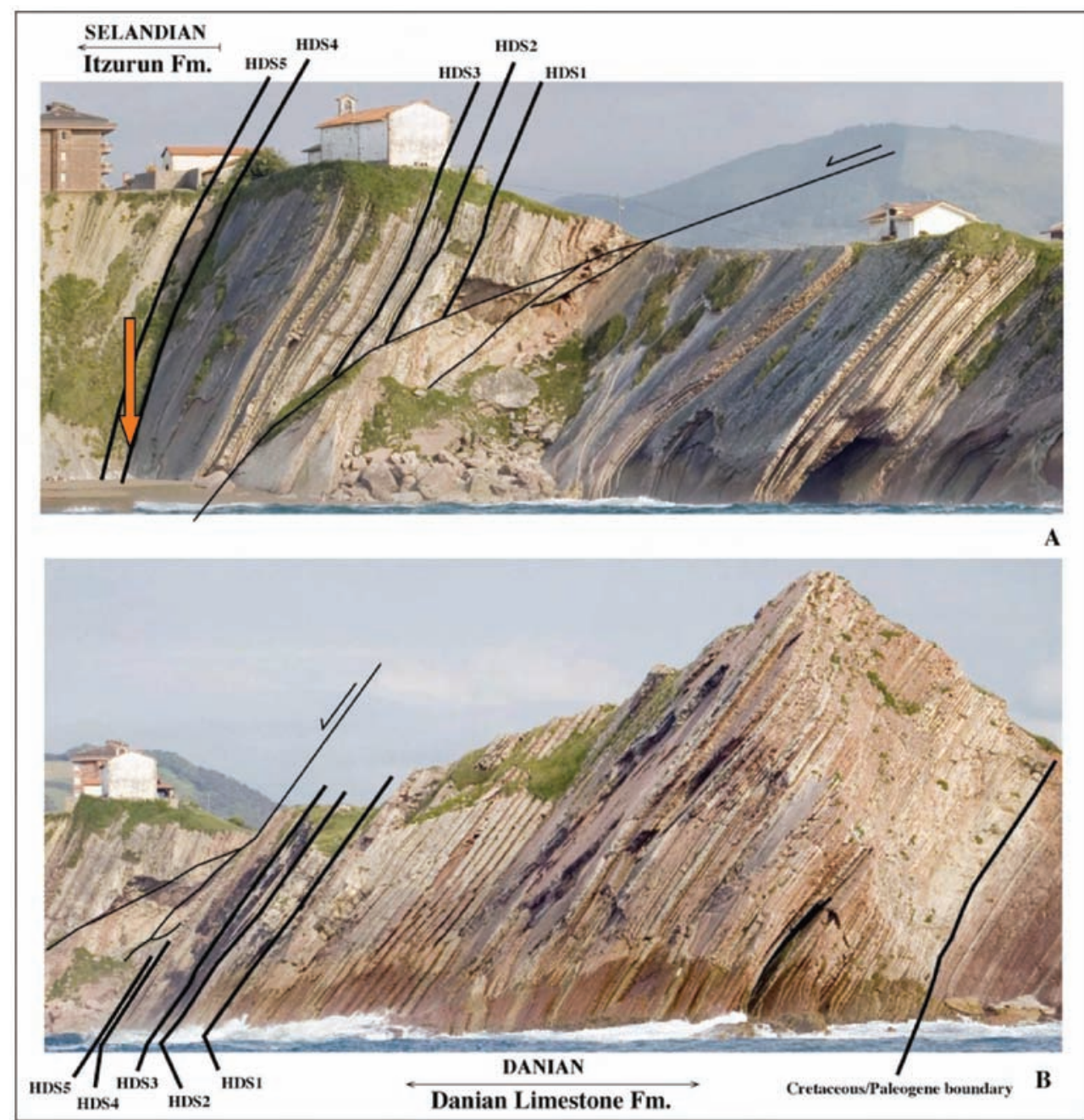

Figure 5. Panoramic photographs of the Danian and Danian-Selandian transition at Zumaia. The reference surfaces HDS1 to HDS5 are discussed in the text and shown in greater detail in Fig. 9. Surface HDS4 corresponds to the defined base of the Selandian Stage, marked by orange arrow. (A) Stratigraphic positions of the horizons HDS1 to HDS5 in the upper block of a normal fault that affects the Danian-Selandian transition. (B) Stratigraphic positions of the Cretaceous/Paleogene boundary and the horizons HDS1 to HDS5 in the lower block of the fault. In (A) and (B), note the repetition of the upper Danian sequence along the section because of the fault. From Arenillas et al. (2008).

Selandian (Schmitz et al. 1998; Bernaola et al. 2009). Another important global nannofossil event is a major radiation of the fasciculiths, which starts slightly below the top of the Aitzgorri Limestone Formation, where the FO of F. ulii s.s. is recorded and continues through the base of the Itzurun Formation, where the FOs of F. billii, F. janii, F. involutus, F. tympaniformis and F. pileatus are recorded (Bernaola et al. 2009). This radiation is here named the second radiation of the fasciculiths because an earlier radiation of small Fasciculithus is recorded $10.2 \mathrm{~m}$ below the top of the Aitzgorri Limestone Formation. An important regional event is the last common occurrence (LCO) (or the end of the acme) of the Braarudosphaera. This genus exhibits an abrupt decline in the relative and absolute abundance in connection with the shift from the Aitzgorri Limestone Formation to the Itzurun Formation. Other important nannofossil events recorded in the stratigraphic sequence at Zumaia include the first rare occurrence of Neochiastozygus perfectus in the uppermost part of the Aitzgorri Limestone Formation and the FO of
Chiasmolithus edentulus, which marks the base of Subzone NTp7b of Varol (1989), ca. $10 \mathrm{~m}$ below the top of the Aitzgorri Limestone Formation (Schmitz et al. 1998; Bernaola et al. 2009). In summary, the sequence of calcareous nannofossil events shows that the Zumaia section is continuous over the Danian-Selandian transition. This is also confirmed by comparison with the calcareous nannofossil record of ODP Site 1262 of Leg 208 at Walvis Ridge (South Atlantic) where an expanded and continuous Paleocene deep-sea sequence has been recovered (Agnini et al. 2007; Monechi and Reale 2007).

\section{Planktonic and benthic foraminifera}

The preservation of foraminifera is moderate in the Zumaia section, hence some taxonomic problems arise, with different researchers using different taxonomic concepts and diagnostic criteria. Problems in the definition of planktonic foraminiferal zone boundaries in the Zumaia section have been carefully evaluated by e.g. Caballero (2007) and Orue-Etxebarria et al. (2007a). Once these definitions are untangled and agreed upon, boundaries can be placed with high precision, giving strong support for the continuity of the Zumaia section across the mid-Paleocene.

Based on planktonic and benthic foraminifera, isotopic and lithologic data, Arenillas et al. (2008) have located five significant event horizons that have been considered as potential correlation criteria for the Danian/Selandian boundary (Figs. 5 and 9). The sequence of foraminifera events at Zumaia and comparisons with sections elsewhere also give support for that the Zumaia section is continuous and expanded. Level HDS1, ca. $13 \mathrm{~m}$ below the top of the Aitzgorri Limestone Formation, is characterized by increases in Acarinina, Karrerulina and Spiroplectammina, and corresponds to the lower boundary of the Morozovella angulata Zone; some authors formerly placed the Danian/Selandian boundary at this biohorizon, i.e. at the P2/P3 zonal boundary (Berggren 1994; Berggren et al. 1995; Steurbaut et al. 2000). HDS2, ca. $9 \mathrm{~m}$ below the top of the Aitzgorri Limestone Formation, is characterized by an increase in Morozovella and corresponds to the lower boundary of the Morozovella cf. albeari Zone by Arenillas and Molina (1997). The lower boundary of the Morozovella occlusa Zone of Orue-Etxebarria et al. (2007b) occurs ca. $7 \mathrm{~m}$ below the top of the Aitzgorri Limestone Formation. HDS3, ca. $7.5 \mathrm{~m}$ below the top of the Aitzgorri Limestone Formation, is characterized by an increase in Karrerulina and maximum values in 


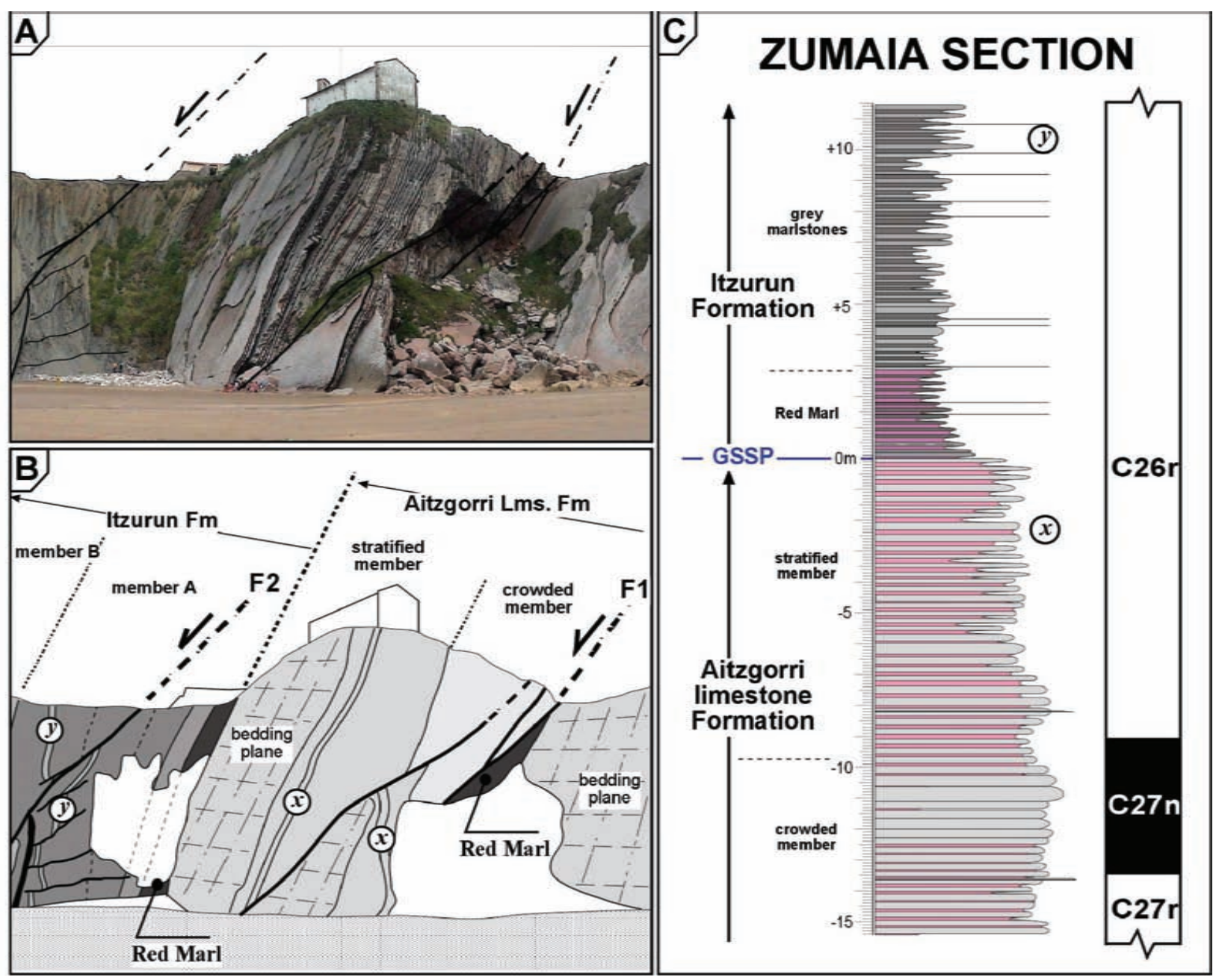

Figure 6. (A) Panoramic view of the Danian-Selandian transition; (B) Synthetic sketch of the Danian-Selandian transition outcrop in the Itzurun Beach, showing the distribution of the main lithological units/members and the fault systems that disrupt the succession. $(C)$ Detailed litholog of the Danian-Selandian transition. $(x)$ and $(y)$ reference levels in sketch $B$ and $C$. From Baceta et al. (2006) and Bernaola et al. (2009).

percentages of Morozovella, coincident with a shift in color of the limestone-marl couplets from greyish to more reddish. HDS4, which occurs at the base of the Itzurun Formation, may correspond to the lower boundary of the Igorina pusilla Zone, as defined by Arenillas et al. (2008). Other features noted at this level are a slight decrease in Morozovella and increases of trochamminids and Spiroplectammina. HDS5, ca. $3 \mathrm{~m}$ above the base of the Itzurun Formation, coincides with the shift from basal red to grey Selandian marls. Minimum values in the percentages of Morozovella and maximum values for Bifarina are recorded here.

Benthic foraminifera give detailed information about the paleobathymetry at Zumaia. The presence of organically cemented and calcareous-cemented agglutinated foraminifera of the "flysch type" fauna, suggests a minimum water depth corresponding to lowermiddle bathyal depths. The benthic foraminiferal assemblages also contain abundant taxa typical of deep bathyal environments such as Bulimina trinitatensis, Cibicidoides hyphalus, Cibicidoides velascoensis, Gyroidinoides globosus, Stensioeina beccariiformis, Nuttallides truempyi, Osangularia velascoensis, Nuttallinella florealis, Gaudryina pyramidata and Spiroplectammina spectabilis. Most of these species are typical of the Velasco-type fauna (Berggren and Aubert 1975). These data support depths of ca. 900-1100 meters or middle to lower slope, in agreement with Pujalte et al. (1995). In spite of the sea-level fall that has been documented for the base of the Selandian (see below), benthic foraminifera show no major changes in coincidence with that level, probably because their deep habitat (a thousand meters depth) would not be affected even by a major sealevel fall (Arenillas et al. 2008).

\section{Magneto- and cyclostratigraphy}

The Zumaia section has provided an unprecedented integrated biomagneto- and cyclostratigraphy for the Paleocene (Dinarès-Turell et al. 2002, 2003, 2007, 2010). The section now provides the first complete astronomically derived Paleocene chronology where all polarity chrons have been established, rendering this section a master reference section. The base of the Selandian occurs approximately at the top of the lower third of Chron C26r. The next lower magnetochron, the top of Chron $\mathrm{C} 27 \mathrm{n}$ occurs ca. $9 \mathrm{~m}$ below and this chron spans ca. $4.5 \mathrm{~m}$ of section (Fig. 8). The cycle-duration estimates for the critical chronozones across the upper Danian and the DanianSelandian transition are as follows: $\mathrm{C} 27 \mathrm{r}$ (50 precession cycles, 1050 kyr), C27n (15 precession cycles, $315 \mathrm{kyr}$ ), and C26r (133 precession cycles, $2793 \mathrm{kyr}$ ). The base of the Itzurun Formation is located 30 


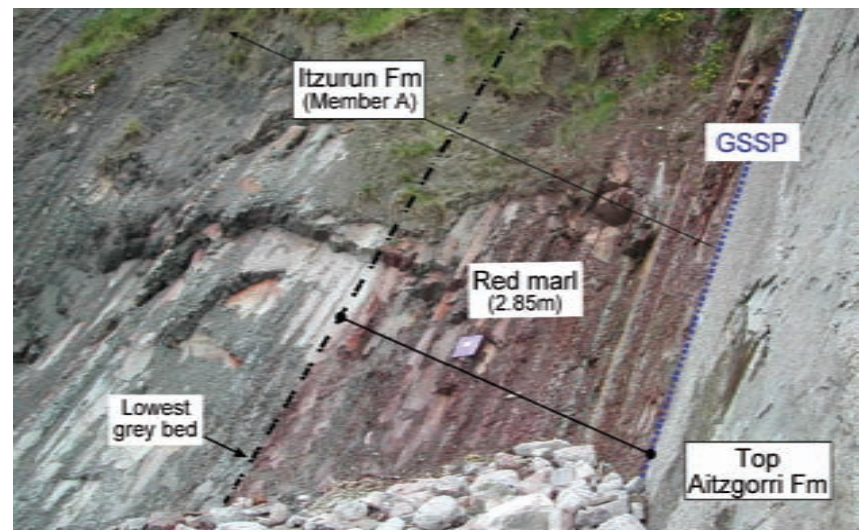

Figure 7. The transition from the $2.85 \mathrm{~m}$ of red marls to the first grey beds in the lower part of the Itzurun Formation, see white square in Fig. 4 for precise location. Red beds occur up to ca. 3.5 $m$, after which beds turn completely grey.

precession cycles ( $630 \mathrm{kyr}$ ) above the top of $\mathrm{C} 27 \mathrm{n}$. Precession cycles can also be used for approximate estimates of relative time difference between different lithologic and biostratigraphic events. For example, the onset of the second radiation of the fasciculiths and the FO of F. tympaniformis occur respectively $21 \mathrm{kyr}$ before and 84-105 kyr after the Danian/Selandian boundary (Bernaola et al. 2009). According to some generalized stratigraphic schemes (e.g., Berggren et al. 1995, Luterbacher et al. 2004) the top of Chron $\mathrm{C} 27 \mathrm{n}$ is considered to coincide with the planktonic foraminifera $\mathrm{P} 2 / \mathrm{P} 3$ zonal boundary, i.e. the level where also the Danian/Selandian boundary has been placed by convention in the past. In the Zumaia section Dinarès-Turell et al. (2007) place the P2/P3 boundary ca. $8 \mathrm{~m}$ below the top of C27n, whereas Arenillas et al. (2008) place this boundary $9 \mathrm{~m}$ higher, i.e. one meter above the top of $\mathrm{C} 27 \mathrm{n}$. This discrepancy in foraminiferal zone boundaries relates to the use of different taxonomic concepts and illustrates the general difficulty in placing precise boundaries in a gradual, evolutionary sequence of morphological change in foraminifera species (Caballero 2007; Orue-Etxebarria et al. 2007a).

A robust Astronomical Polarity Time Scale (APTS) has been constructed during the last two decades, starting at the young end of the time scale and then moving progressively deeper in time. A recent achievement in this effort has been the completion of an astronomical time scale for the Neogene, resulting in the "Astronomically Tuned Neogene Time Scale" (Lourens et al. 2004). Tuning the Paleogene becomes more challenging despite new full numerical solutions for the Solar System (Varadi et al. 2003; Laskar et al. 2004) due to limitations inherent to the chaotic behaviour of the Solar System and

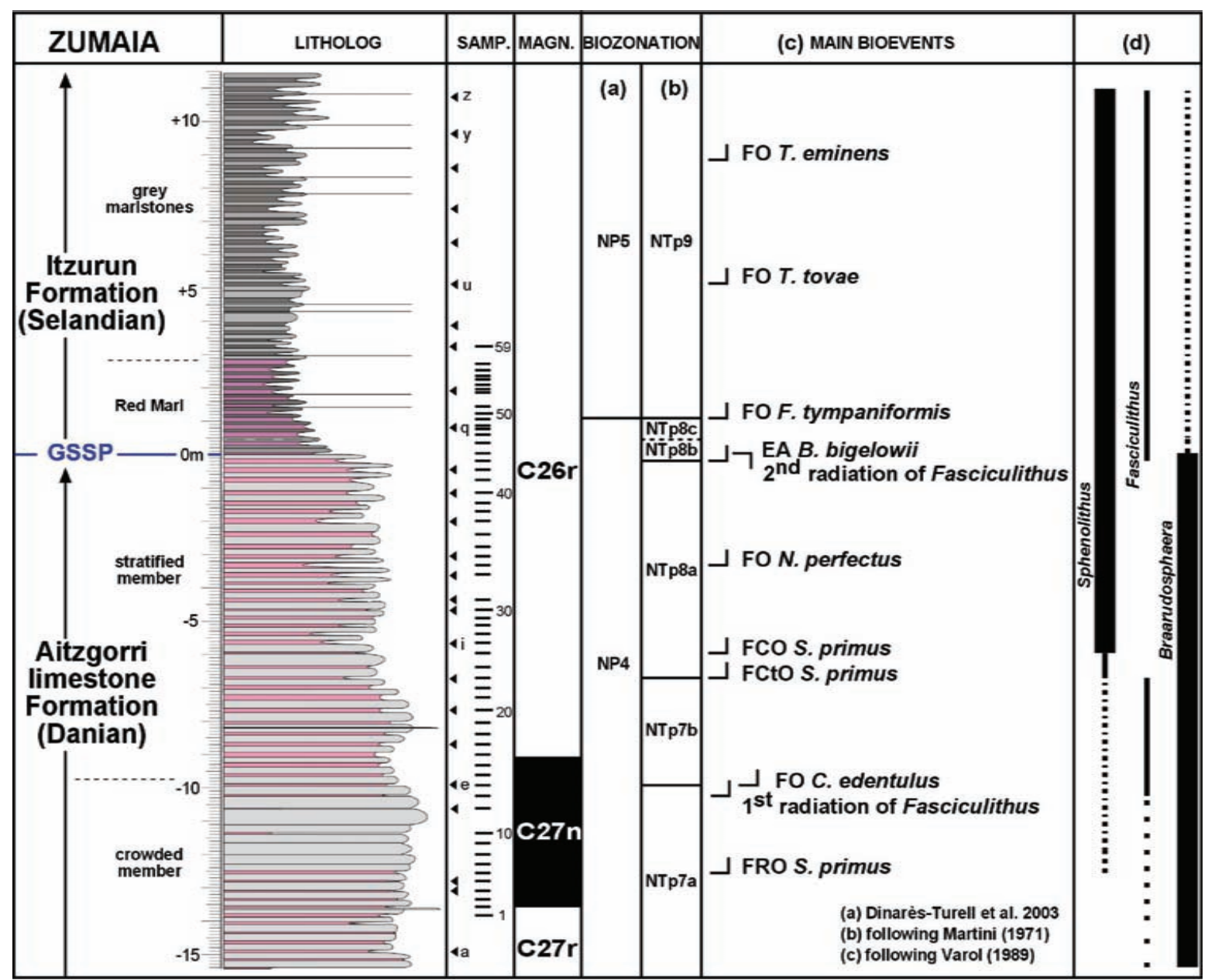

Figure 8. Integrated lithostratigraphy, magnetostratigraphy and calcareous nannofossil biostratigraphy of the Danian-Selandian transition of the Zumaia section. Location of the main bioevents and synthetic distribution and abundance ranges of Sphenolithus, Fasciculithus and Braarudosphaera. FO= First Occurrence; FRO= First Rare Occurrence $;$ FCtO= First Continuous Occurrence; FCO= First Common Occurrence; EA= End of Acme. From Bernaola et al. (2009). 


\section{ZUMAIA SECTION}

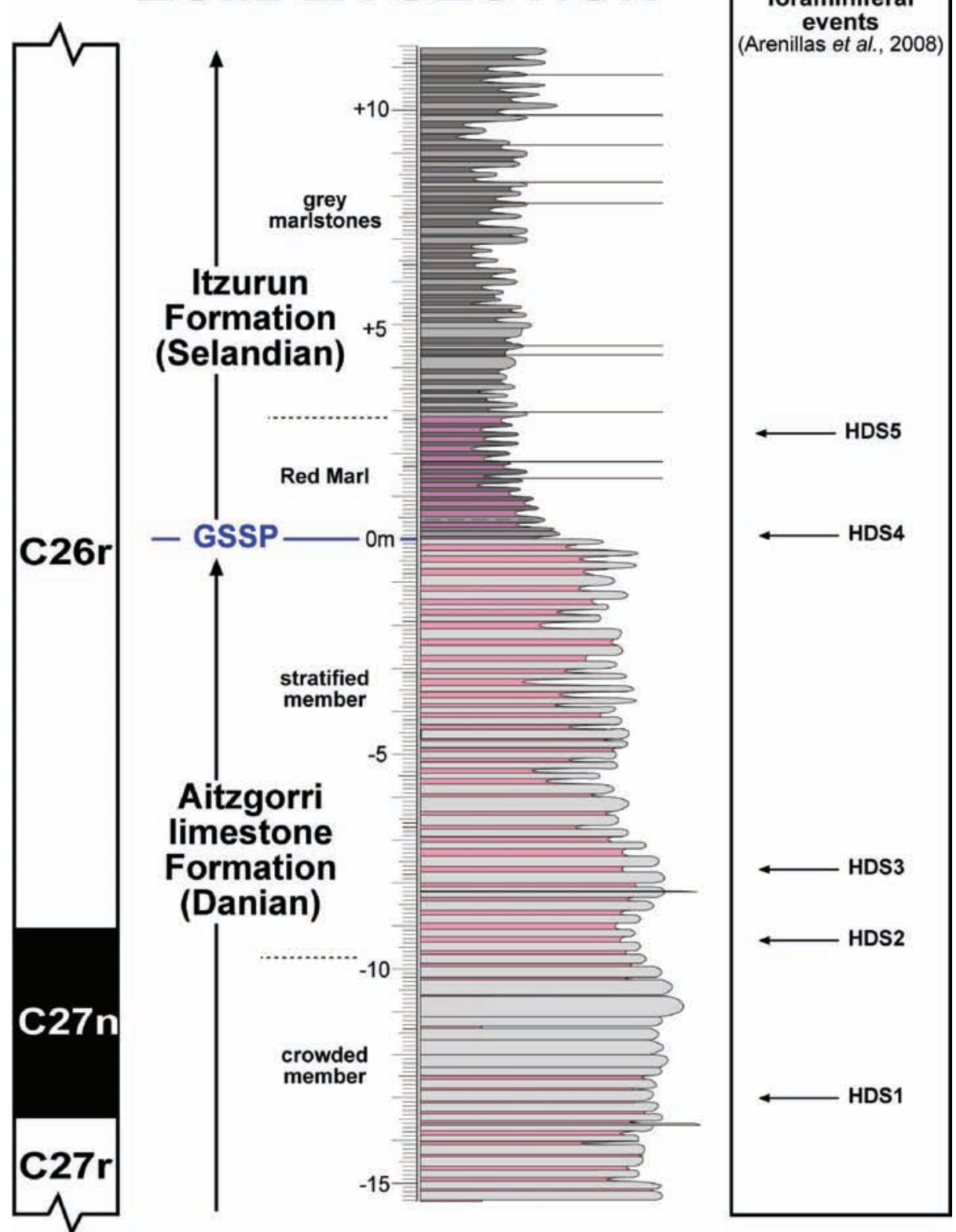

Figure 9. Detailed lithological log across the Danian-Selandian transition of the Zumaia section with position of reference horizons HDS1 to HDS5 (Arenillas et al. 2008). These horizons are discussed in the main text and shown in Fig. 5. Surface HDS4 corresponds to the base of the Selandian. Magnetostratigraphy from Dinarès-Turell et al. (2003).

poor radioisotopic age control in the Paleocene in addition to uncertainties in the absolute numerical age of the monitor standards used for the radioisotopic dating methods (Kuiper et al. 2008). However, astronomical tuning based on the stable 404-kyr eccentricity cycle is appropriate (Westerhold et al. 2008) and should be the firstorder approach to reach a consistent Paleocene tuned chronology. Although precise orbital solutions for shorter cycles are lacking, a suitable approach is to establish an integrated magnetostratigraphic and orbitally characterized template (i.e. cycle-duration estimates and main phase relationships) in a given succession. Even if definitive tuning to an orbital solution (and therefore "absolute" age estimates) may be provisional, the time duration and rate of processes (i.e. biological, paleoclimatic etc.) are readily extracted. Moreover, the potential for global correlation is amply facilitated.
Dinarès-Turell et al. (2003) tuned the orbitally driven lithological Danian bundles at Zumaia (their E-cycles) to the Va03_R7 eccentricity solution target (Varadi et al. 2003). Tuning was started by correlating two consecutive prominent carbonate-rich bundle cycles (E-35 and E-36), at about 38 $\mathrm{m}$ above the Cretaceous/Paleogene boundary, to respective eccentricity cycles at a peculiar low-amplitude eccentricity minima node in the solution target, which is related to the very long ca. $2.8 \mathrm{Myr}$ eccentricity modulation cycle. The tuning subsequently progressed by correlating successive eccentricity bundles in the section to successive eccentricity minima. Following the tuning, Dinarès-Turell et al. (2003) arrive at an age of $65.830 \mathrm{Ma}$ for the Cretaceous/ Paleogene boundary. Kuiper et al. (2008) instead use an alternative strategy of cycle pattern recognition and tuning to the more stable 405-kyr long eccentricity cycle and incorporate the La04 solution (Laskar et al. 2004) as target. Inferences from numerical dating elsewhere led Kuiper at al. (2008) to propose two alternative tuning schemes for each astronomical target solution. The favored one, resulted identical to the one proposed by Dinarès-Turell et al. (2003) for most of the Danian. It is only below eccentricity bundle E-14 (at about $17 \mathrm{~m}$ above the Cretaceous/Paleogene boundary), that they choose to calibrate to one eccentricity cycle older, reaching an age of 65.940 Ma for the Cretaceous/Paleogene boundary in the Va03_R7 target. Hilgen et al. (2010), while maintaining their previous tuning for Zumaia, amend at several levels the Paleocene astronomical calibration proposed by Westerhold et al. (2008) which is based on different geochemical data sets from ODP/IODP sediments from different oceans and their own interpretation and attempt to correlate to Zumaia. In turn, Dinarès-Turell et al. (2010) refine the top position of Chron $\mathrm{C} 27 \mathrm{n}\left(\mathrm{C} 27 \mathrm{n}_{\text {top }}\right)$ by integrating new magnetostratigraphic data from Zumaia and the Bjala section in Bulgaria. $\mathrm{C} 27 \mathrm{n}_{\text {top }}$ is now placed four precession cycles above the position originally reported in Dinarès-Turell et al. (2003). Dinarès-Turell et al. (2010) also reassess the astronomical tuning of the DanianSelandian transitional interval in the light of the expression of the 405-kyr eccentricity cycle both in the land-based sections and for IODP Site 1262. They provide a consistent correlation of the various data sets that challenge the previous interpretation of Westerhold et al. (2008). As for the position of the basal Selandian GSSP at Zumaia it is located 30 precession cycles above $\mathrm{C} 27 \mathrm{n}_{\text {top }}$ (ca. $630 \mathrm{kyr}$ ) and can be assigned an age of $61.641 \pm 0.040 \mathrm{Ma}$ on the La04 astronomical target solution (see Dinarès-Turell et al. 2010, for further details). 


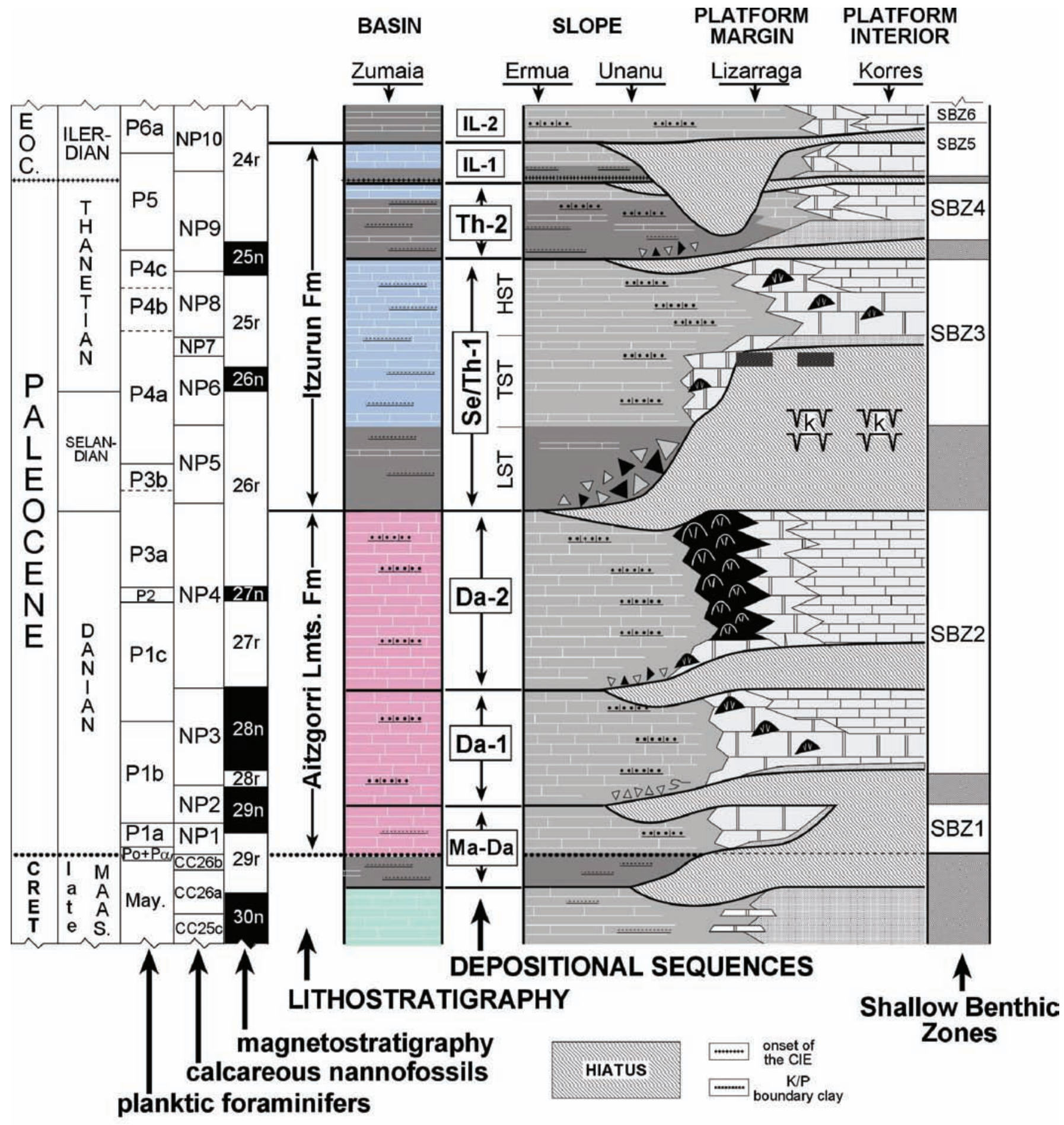

\begin{tabular}{|c|c|c|c|c|}
\hline \multicolumn{3}{|c|}{ Shallow marine deposits } & \multicolumn{2}{|c|}{ Slope and basin deposits } \\
\hline$\rightarrow$ & reefal & louter platform limestones & \multirow{4}{*}{$\begin{array}{l}\text { autochtonous } \\
\text { (hemi)pelagic } \\
\text { limestones } \\
\begin{array}{l}\text { marls \& } \\
\text { marlstone }\end{array} \\
\end{array}$} & resedimented \\
\hline 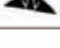 & constructions & (I"shoals" \& bioclastic accumulations) & & siliciclastic \\
\hline $\begin{array}{ll}\sqrt{k} r \\
\sqrt{r}\end{array}$ & $\begin{array}{l}\text { deep } \\
\text { karstification }\end{array}$ & $\begin{array}{l}\text { inner platform limestone/dolostones } \\
\text { (lagoon \& tidal flats) }\end{array}$ & & $\begin{array}{l}\text { turbidites } \\
\ldots \text { calcareous } \\
\text { turbidites }\end{array}$ \\
\hline & paleosoils & $\begin{array}{l}\text { shallow marine siliciclastics } \\
\text { (beach, delta and open platform) }\end{array}$ & & $\begin{array}{l}\nabla \Delta \nabla \text { conglomerates } \\
\text { \& breccias }\end{array}$ \\
\hline
\end{tabular}

Figure 10. Biochronostratigraphic framework of the Paleocene to lower Ypresian (regional Ilerdian) succession of the SW Pyrenees, showing depositional sequences and main facies. Age dating of the sequences based on platform margin, slope and basinal sections. For location of reference sections, see Fig. 3. Modified from Baceta et al. (2004). 


\section{Carbon isotope stratigraphy}

A detailed carbon isotope stratigraphy has been established through the entire Paleocene section at Zumaia based on bulk rock samples (Schmitz et al. 1997a, 1998). This isotopic record shows the same general $\delta^{13} \mathrm{C}$ trend as records measured in well-preserved deep-sea material, such as at Deep Sea Drilling Project Site 577. The characteristic global late Paleocene $\delta^{13} \mathrm{C}$ maximum (Corfield 1994; Westerhold et al. 2011) is well represented at Zumaia. Two major and two minor negative $\delta^{13} \mathrm{C}$ shifts are registered. The two major shifts (> 1\%o) are situated at the Cretaceous/Paleogene and Paleocene/ Eocene boundaries. The two minor shifts $(<1 \%)$ are located near the top of the Aitzgorri Limestone Formation and in the basal Itzurun Formation. The first two anomalies have also been found in many other sections worldwide, whereas it has been generally difficult to reproduce the two other anomalies elsewhere. For example, the continuous mid-Paleocene record at Deep Sea Drilling Project Site 384 in the northwest Atlantic (Berggren et al. 2000) does not show a clear negative $\delta^{13} \mathrm{C}$ spike similar to the one observed by Schmitz et al. (1997a, 1998) at the base of the Selandian at Zumaia. At both localities, however, the inflection point of the increase in $\delta^{13} \mathrm{C}$ that eventually culminates in the unusually high $\delta^{13} \mathrm{C}$ values during the long-term late Paleocene $\delta^{13} \mathrm{C}$ maximum, occurs very close to the boundary between calcareous nannofossil zones NP4 and NP5. This feature can apparently be used at least for first-order correlations between different sites. Westerhold et al. (2011) in a carbon isotope record for the Paleocene from the central Pacific, show small negative anomalies that may correspond to the smaller anomalies at Zumaia.

The short-term negative spike in $\delta^{13} \mathrm{C}$ at the base of the Selandian at Zumaia may at least partly be related to local features associated with the prominent sea-level fall at this event (see later section). It is clear that in surface waters there is a gradient towards more negative $\delta^{13} \mathrm{C}$ values landward because of an increasing contribution of landderived organic detritus. A sea-level fall may have shifted the coastline closer to Zumaia. The small (ca. $0.7 \%$ ) negative $\delta^{13} \mathrm{C}$ anomaly of short duration that occurs at ca. $10 \mathrm{~m}$ below the base of the Itzurun Formation (Schmitz et al. 1997a), in the lower part of Chron C26r and at HDS2 in Figs. 5 and 9, may be correlated to the Latest Danian Event as observed in Egypt (Bornemann et al. 2009; Sprong et al. 2009) and the Indian Ocean (Quillévéré et al. 2002; Bornemann et al. 2009).

\section{Sequence stratigraphy}

The deep-water Zumaia embayment was bordered by shallowwater areas in which a $300-500 \mathrm{~m}$ thick carbonate succession was formed by the vertical stacking of consecutive carbonate platforms (Fig. 3). Development of this carbonate succession was punctuated by sea-level lowerings of at least regional extent, during which the platform top was subaerially exposed, platform growth ceased and extensive discontinuity surfaces were created (Baceta 1996; Baceta et al. 2001, 2007). During the Paleocene-early Ypresian interval six such drops have been identified, the inherent discontinuities having been used to subdivide the succession into depositional sequences, coded according to their age (Fig. 10; Pujalte et al. 2000; Baceta et al. 2004, 2007). The most prominent of these discontinuities, the socalled Mid-Paleocene Unconformity (Baceta et al. 2001), marks the base of the Se/Th-1 sequence. It was created during a long-lasting period of low sea level (of ca. 2.5 Myr according to biostratigraphic constraints, see Baceta et al. 2005) that triggered large erosional collapses of the upper Danian slopes and shelf margins and prompted the deep karstification of the exposed platform carbonates across the whole Pyrenean basin margin (Baceta et al. 2001, 2004, 2007). The basal Selandian here represents the correlative conformity in the basinal succession of this major unconformity identified in the shallow platform areas. According to a detailed stratigraphic reconstruction of the shelf margin area cropping out in the Urbasa-Andia plateau and through the use of depth-indicating key facies below and above the Mid-Paleocene Unconformity it has been estimated that in the Pyrenean basin the minimal magnitude of the sea-level fall of the Danian-Selandian transition was between $80-90 \mathrm{~m}$. The origin of this prominent sea-level drop is still uncertain but it mainly seems to be related to a major tectonic inversion across the interior of the European plate (Nielsen et al. 2005), presumably linked to uplift of the North Atlantic lithosphere by the Iceland plume (White and Lowell 1997).

\section{The GSSP for the Thanetian - position, stratigraphy and completeness}

\section{Precise position}

The base of the Thanetian Stage, the third or upper stage in the Paleocene Series, is placed in the section at Itzurun Beach in Zumaia at a level $2.8 \mathrm{~m}$ above the base of the core of the distinct clay-rich interval associated with the Mid-Paleocene Biotic Event (MPBE) (Figs. 11-15). The base of the Thanetian corresponds to the base of magnetochron C26n (i.e., C26r/C26n reversal) in the section (DinarèsTurell et al. 2007). It also corresponds to the level eight precession cycles above the base of the core of the MPBE (Figs. 11-15), an event characterized by important calcareous nannofossil and foraminifer assemblage changes (Bernaola et al. 2007; Dinarès-Turell et al. 2007). The base of the Thanetian occurs ca. $29 \mathrm{~m}$ above the base of the Selandian, and ca. $78 \mathrm{~m}$ above the Cretaceous/Paleogene boundary.

\section{Lithostratigraphy}

The Itzurun Formation that spans the entire Selandian and continues up through the lower Thanetian, shows higher vertical variations in both the relative proportion of hemipelagic sediments and the amount of turbidite intercalations compared to the underlying Aitzgorri Limestone Formation (Baceta et al. 2006). The lower part of the Itzurun Formation can be divided in a lower, ca. $24 \mathrm{~m}$ thick, (informal) Member A, and an upper, ca. $52 \mathrm{~m}$ thick Member B (Fig. 13). Member A is largely dominated by marls, whereas Member B includes significant proportions of indurated limestone. The boundary between the two members has been established arbitrarily at the point in which limestone beds reach and maintain $\mathrm{CaCO}_{3}$ values higher than $60 \%$. This boundary is situated ca. $6.5 \mathrm{~m}$ below the defined base of the Thanetian. On a larger scale, members A and B of the Itzurun Formation record a progressive increase in $\mathrm{CaCO}_{3}$, after the abrupt decrease that characterizes the lower boundary of the formation. The $\mathrm{CaCO}_{3}$ increase culminates in the upper part of Member $\mathrm{B}$ with values similar to those of the Aitzgorri Limestone Formation. The composition of the limestones in the Itzurun Formation is rather similar to those in the underlying Aitzgorri Limestone Formation (micritic mudstone-wackestone with planktonic foraminifera), but occasionally 


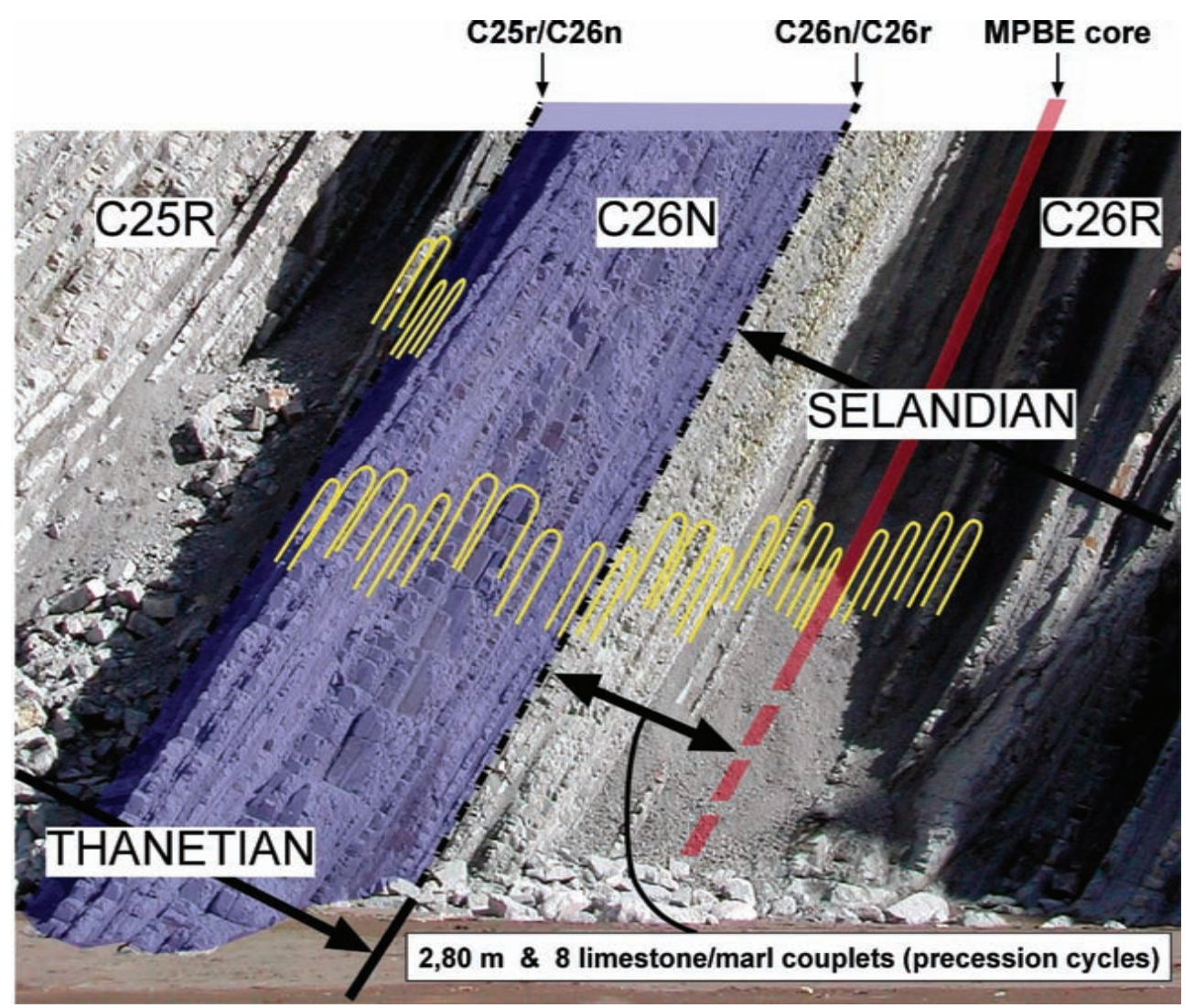

Figure 11. Position of the base of the Thanetian Stage at Itzurun Beach. The relationship of the GSSP relative to magnetostratigraphy and lithology is emphasized. Magnetostratigraphy according to Dinarès-Turell et al. (2007).

they also contain minor amounts of silt-sized quartz and glauconite, this latter as sub-mm grains and infillings of the foraminiferal tests (Baceta et al. 2006). The Itzurun Formation records a progressive change from illite-rich to illite/smectite-rich clays. Trace fossils, dominated by Zoophycos, are common. The Itzurun Formation differs from the Aitzgorri Limestone Formation also in the amount and type of turbidite intercalations. In the marly Member A they are predominantly of siliciclastic nature, whereas in Member B, which shows a higher number, they are usually of siliciclastic or mixed carbonaticsiliciclastic nature. The carbonate grains mainly correspond to abraded tests of planktonic foraminifera. About three meters above the limit between the members A and B of the Itzurun Formation, there is a prominent dark ca. $1 \mathrm{~m}$ thick interval recording a drastic decrease in $\mathrm{CaCO}_{3}$ and relatively high values in magnetic susceptibility. This clay interval is interpreted as the expression of the Mid-Paleocene Biotic Event (Bernaola et al. 2007).

\section{Calcareous nannofossils}

The stratigraphic interval spanning the Selandian Stage and the Selandian/ Thanetian boundary is characterized by a smoothly evolving succession of calcareous nannofossils (Figs. 13 and 15), similar to records in apparently expanded and continuous successions elsewhere, such as in the deep sea (Bernaola and Nuño-Arana 2006; Dinarès-Turell et al. 2007; Bernaola et al. 2009). Close to the boundary between the basal $2.85 \mathrm{~m}$ of red marl and the overlying grey marl beds (Member A) in the lower part of the Itzurun Formation, occurs a slight decrease in total abundance of calcareous nannofossils, but no other significant change is recorded. The calcareous nannofossil assemblage across the grey marlstones (Member A) of the Itzurun Formation is similar to that found in the underlying red marl and is mainly dominated by Coccolithus pelagicus, Prinsius martinii, $P$.

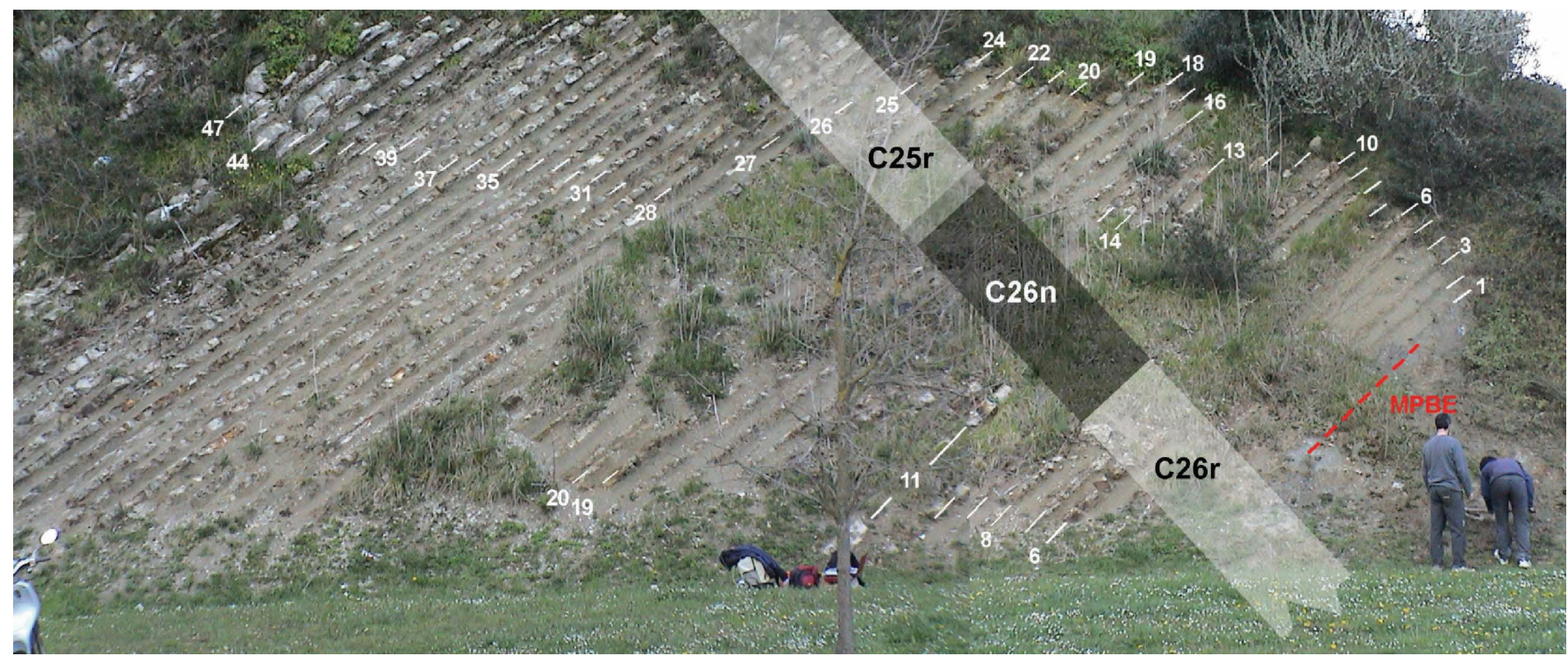

Figure 12. Position of magnetochrons C26r, C26n and C25r in relation to lithology in the Ibaeta section, a complementary reference section for magnetostratigraphy across the Selandian-Thanetian transition. Magnetostratigraphy according to Dinarès-Turell et al. (2007). 


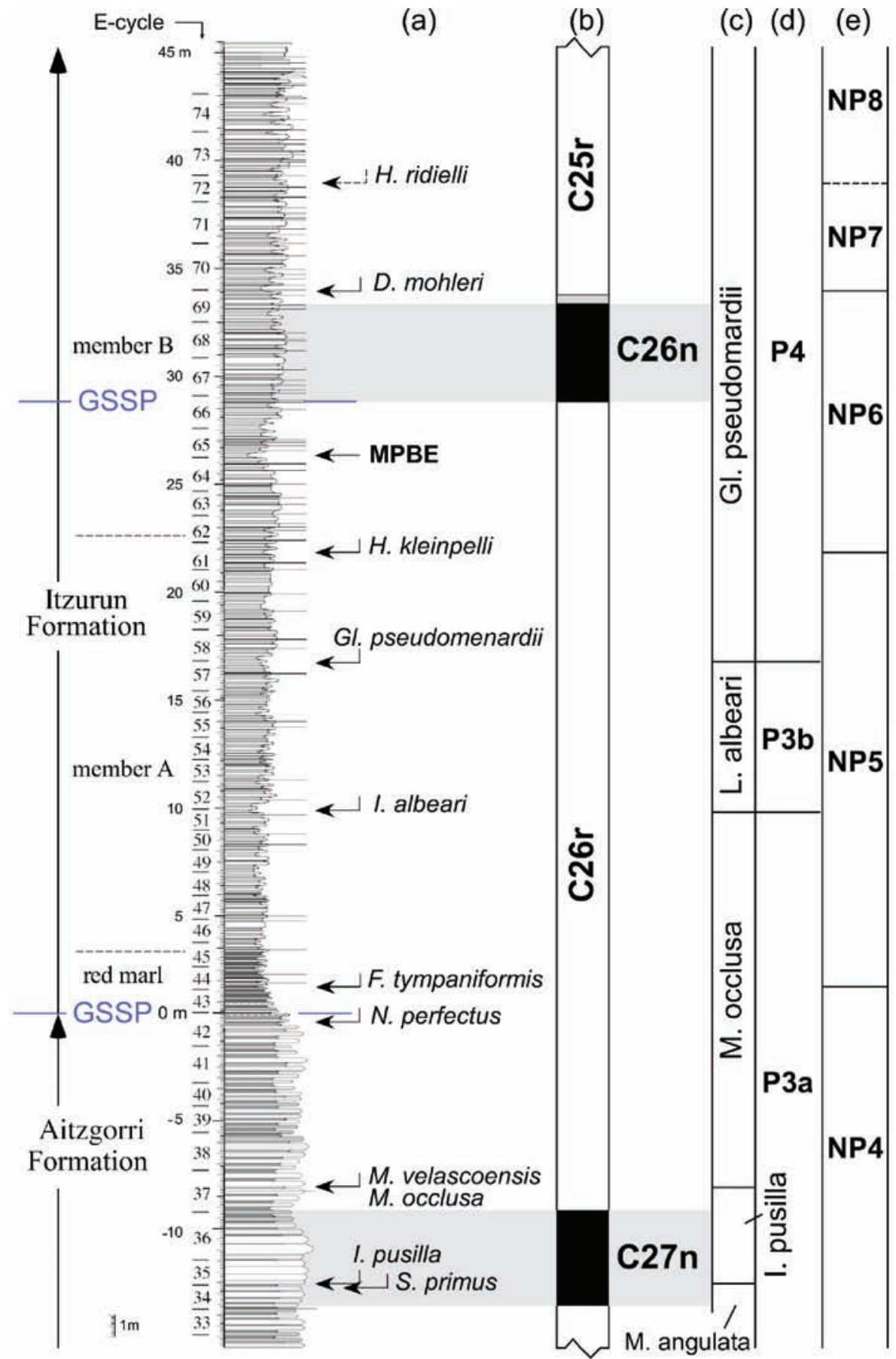

Figure 13. Integrated lithostratigraphy, biostratigraphy and magnetostratigraphy of the midPaleocene of the Zumaia section. (A) Main calcareous plankton bioevents. (B) Magnetic polarity stratigraphy. (C) Planktonic foraminifera biozonation. (D) Biozonation of Berggren et al. (1995). (E) Calcareous nannofossil biozonation. Biostratigraphic events represent first occurrences. From Baceta et al. (2006) and Dinarès-Turell et al. (2007).

bisculus and Toweius pertusus. The most important change in the calcareous nannofossil assemblages across the A and B members of the Itzurun Formation is the occurrence and diversification of the genus Heliolithus and the first occurrence of the genus Discoaster, one of the most important calcareous nannofossil groups providing numerous biostratigraphic markers throughout the Paleogene. Across the upper A and lower B members of the Itzurun Formation the FOs of Coronocyclus nitescens, Zygodiscus bramlettei, Toweius eminens, Heliolithus cantabriae, Sphenolithus anarropus, Heliolithus kleinpelli, Bomolithus conicus and Discoaster bramlettei, among others are also recorded (Bernaola and Nuño-Arana 2006). The base of Zone NP6, marked by the FO of $H$. kleinpelli occurs ca. $22 \mathrm{~m}$ above the base of the Selandian Stage and ca. $6.5 \mathrm{~m}$ below the bases of Chron C26n and the Thanetian Stage (Dinarès-Turell et al. 2007).

\section{Planktonic foraminifera}

No significant change in the planktonic foraminiferal association has been observed across the base of the Thanetian stage. However, at the onset of the Mid-Paleocene Biotic Event, $2.8 \mathrm{~m}$ below the base of the Thanetian, there is a decrease in both the proportion of the planktonic foraminifera relative to the total foraminifera assemblage (planktonic + benthic) and in the number of planktonic species. At the generic level there is an increase in the proportion of Igorina, and a decrease in the relative abundance of all other species. The lowest relative proportion of planktonic foraminifera and the minimum number of species occur in the upper part of the Mid-Paleocene Biotic Event interval, where most of the specimens preserved belong to the Subbotina genus. These changes, however, were transient, as a return to the conditions that prevailed before the MidPaleocene Biotic Event is observed above the event. A noticeable decrease in the proportion of morozovellids across the Danian/Selandian boundary, from $20-25 \%$ of the total assemblage in the Danian samples, to $10 \%$ or less in the Selandian samples was reported by Orue-Etxebarria et al. (2007b; 2010). OrueEtxebarria et al. (2010) further documented a progressive but systematic change in the coiling direction of Morozovella occlusa, which evolves from having approximately $50 \%$ sinistral and dextral individuals in Danian samples to becoming progressively dominated by a dextral population in the lower few meters of the Selandian succession, so that $10 \mathrm{~m}$ above the base of the Itzurun Formation ca. $80 \%$ of the tests show a predominant dextral coiling. The FO of Igorina albeari, marker of Zone P3b by Berggren and Pearson (2005), occurs ca. $10 \mathrm{~m}$ above the base of the Itzurun Formation (Fig. 13) according to Arenillas and Molina (2000) and Orue-Etxebarria et al. (2007a). The lower boundary of the Zone P4 by Berggren and Pearson (2005), marked by the FO of Globanomalina pseudomenardii, occurs ca. $16 \mathrm{~m}$ above the base of the Itzurun Formation according to OrueEtxebarria et al. (2007a). In the lower part of the Zone P4 there is an increase in planktonic foraminifera diversity, especially in acarininids and globanomalinids. Arenillas and Molina (2000) suggested that the lower boundary of the Zone P4 - or Luterbacheria pseudomenardii 


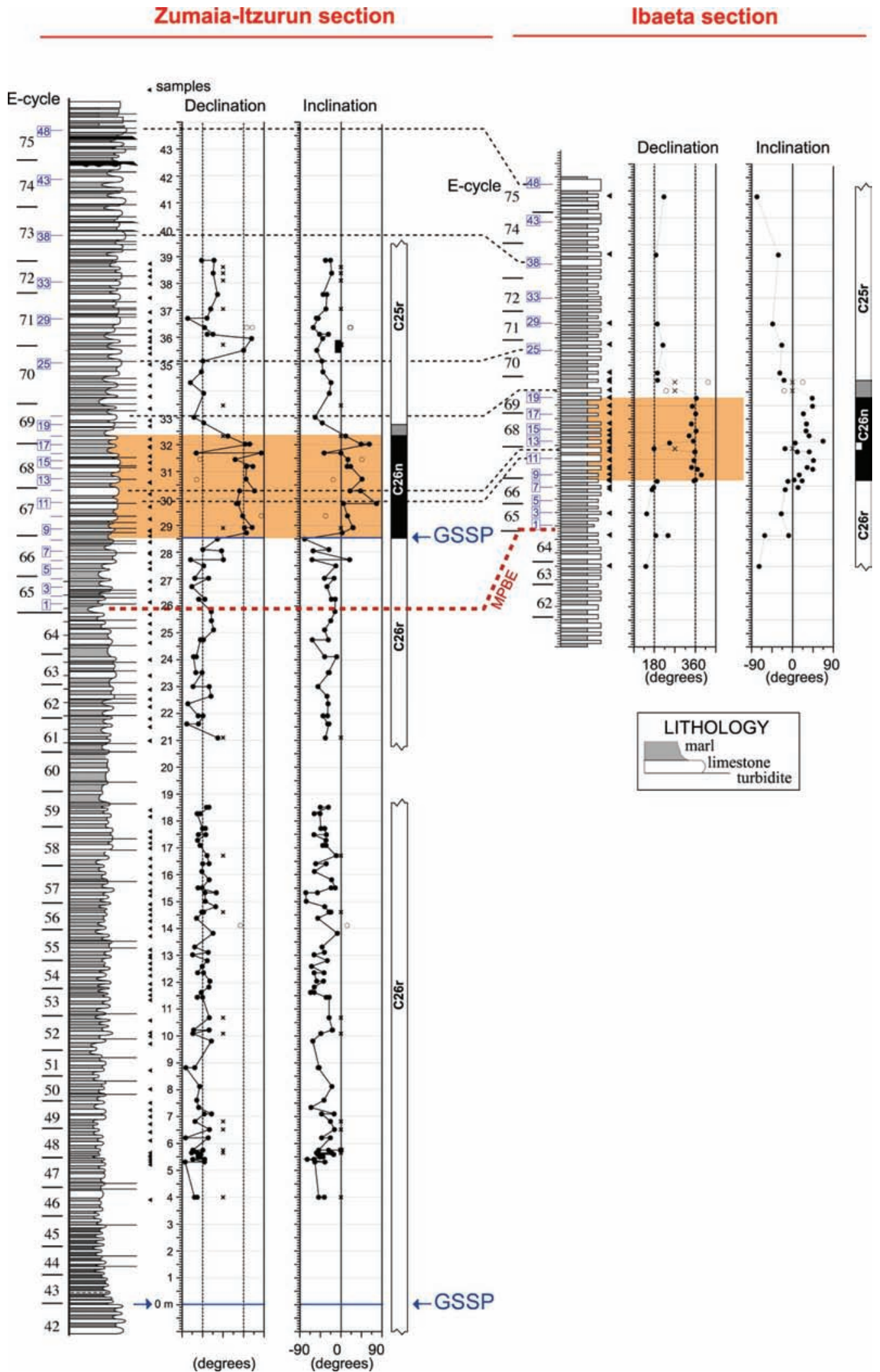

Figure 14. Declination and inclination of the characteristic remanent magnetization (ChRM) components and lithologic logs for the Zumaia-Itzurun and Ibaeta sections. Declinations for the Zumaia section have been unrotated by $20^{\circ}$. Open circles denote unreliable data and crosses mark the position of samples that provided no data. The position of both GSSPs, of Chron C26n and correlation between the sections are shown. MPBE denotes the Mid-Paleocene Biotic Event (Bernaola et al. 2006) and dashed lines correlate some distinct relatively thick carbonate beds. Numbering of the eccentricity (110 kyr) related E-cycles follows numbering for underlying strata that starts above the Cretaceous/Paleogene boundary as reported by Dinarès-Turell et al. (2003). Numbering of the carbonate layers from the basic couplets or precession P-cycles arbitrarily starts at the MPBE event (from Dinarès-Turell et al. 2010, slightly modified). 
E-cycle P-cycle

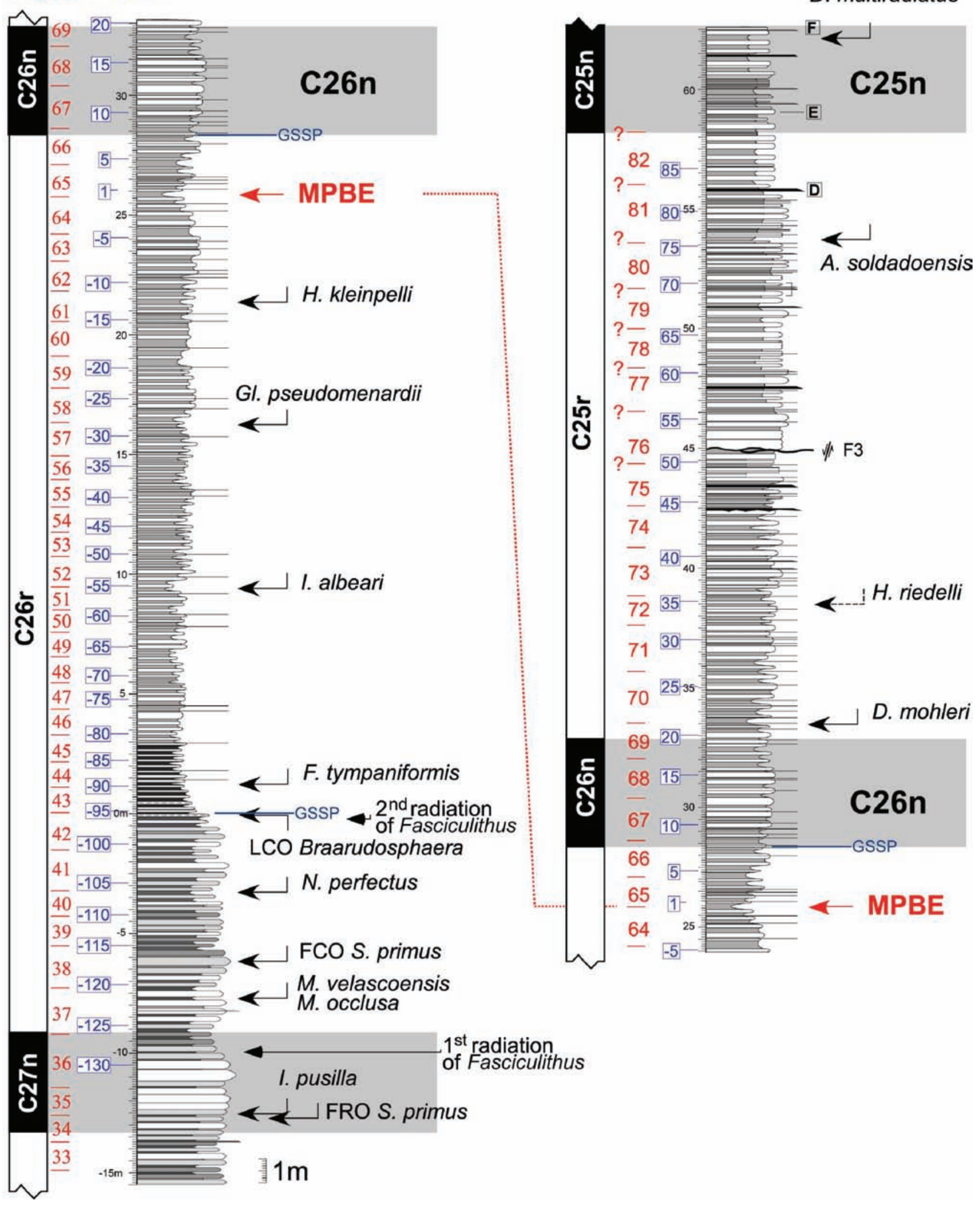

Figure 15. Magnetostratigraphy, main biostratigraphic events, lithology and cyclostratigraphy across the mid-Paleocene in the Zumaia section. MPBE denotes the Mid-Paleocene Biotic Event. Numbering of the eccentricity (ca. 110 kyr) related E-cycles follows numbering for underlying strata that starts above the Cretaceous/Paleogene boundary, reported by Dinarès-Turell et al. (2003). Numbering of the carbonate layers from the basic couplets of precession P-cycles arbitrarily starts at the MPBE. Biostratigraphic events represent first occurrences (FOs), otherwise they are indicated as first common occurrences (FCOs), first rare occurrence (FROs) or last common occurrences (LCOs). From Dinarès-Turell et al. (2007). 
Zone of Arenillas and Molina (1997) - should be placed close to the C26r/C26n boundary at Zumaia.

\section{Magneto- and cyclostratigraphy}

The precise position and duration of Chron C26n has been established by detailed paleomagnetic work in the Zumaia section, and confirmed by complementary work in the nearby Ibaeta section (Figs. 11-15) (Dinarès-Turell et al. 2007). The magnetostratigraphy has been linked to detailed cyclostratigraphy providing an excellent Astronomical Polarity Time Scale. The cycle-duration estimates for the mid-Paleocene critical chronozones where the SelandianThanetian transition occurs are as follows: C26r (133 precession cycles, $2793 \mathrm{kyr}$ ), C26n (11 precession cycles, $231 \mathrm{kyr}$ ) and C25r ( 69 precession cycles, $1449 \mathrm{kyr}$ ). The base of the Thanetian Stage is 105 precession cycles above the base of the Selandian Stage, which indicates a total duration of $2103 \mathrm{kyr}$ for the Selandian Stage. There is no distinct lithological change (e.g., in carbonate content or turbidite abundance) or noticeable biological change in connection with the Chron C26r/C26n reversal, but the level can be located and correlated to other basins by reference to the distinct Mid-Paleocene Biotic Event (see below).

\section{Carbon isotope stratigraphy}

The base of Chron C26r occurs in about the middle of the interval where whole-rock $\delta^{13} \mathrm{C}$ values gradually increase towards maximum values in the late Paleocene. There is no $\delta^{13} \mathrm{C}$ anomaly associated with the base of the Thanetian. In the clayey interval corresponding to the Mid-Paleocene Biotic Event, in addition to a 30\% decrease in carbonate content, a $1 \%$ negative $\delta^{13} \mathrm{C}$ shift is reported by Bernaola et al. (2007), however, such isotopic shifts associated with a change from limestone to marl may not necessarily reflect original trends, because diagenetic minerals can form in the soft marls (Schmitz et al. 1997a). In the Zumaia section reliable isotopic results can primarily be retrieved from the limestone beds. These beds were lithified during early diagenesis which restricted the exchange of isotopes with percolating pore waters.

\section{Sequence stratigraphy}

According to general and detailed correlations carried out between basinal, slope and platform successions in the western Pyrenean basin (Baceta 1996; Pujalte et al. 1998a,b; Baceta et al. 2004, 2005), the Thanetian GSSP occurs within the transgressive systems tract (TST) of depositional sequence Se/Th-1 (Fig. 10). This systems tract is marked at platform margin settings by the onlap of shallow marine upper Selandian and Thanetian strata onto the remarkable MidPaleocene Unconformity capping the shelf Danian carbonates, thus recording the progressive marine re-flooding of the extensive flattopped Danian platforms after the sea-level drop at the DanianSelandian transition (Pujalte et al. 1998a; 2000). This regional reflooding process is recorded in the basinal succession of the Itzurun Formation by a progressive but relatively rapid vertical increase in the calcite content of both limestones and marls, the apparition and increase of authigenic glauconite-infilled foraminiferal tests and the apparition of calcareous turbidites containing platform-derived fossils across the $10 \mathrm{~m}$ thick interval that in the Zumaia section encompasses the Mid-Paleocene Benthic Event (see below) and the magnetochron
C26n (Baceta 1996; Pujalte et al. 1998a,b; Baceta et al. 2006). Similar features are recorded in the nearby Ibaeta section, near San Sebastian, and in typical base-of-slope sections such as Ermua (Baceta 1996), a fact reflecting the direct influence of the sea-level signature on depositional processes taking place across the Pyrenean basin.

\section{Relation to Mid-Paleocene Biotic Event}

A few meters below the base of Chron C26n a global short-lived event of evolutionary significance is recorded and possibly related to a hyperthermal event (Fig. 11) (Bernaola et al. 2007). This so called Mid-Paleocene Biotic Event is represented at Zumaia by a distinct clay-rich interval characterized by important calcareous nannofossil and foraminifer assemblage changes. This interval, which is also characterized by a significant drop in carbonate content and a pronounced peak in magnetic susceptibility, is located ca. $4.5 \mathrm{~m}$ above the first occurrence of H. kleinpelli, the marker species of Zone NP6, and within the planktonic foraminifera Zone P4. This is at a stratigraphic level equivalent to the red clay layer of the Mid-Paleocene Biotic Event found at Shatsky Rise in the Central Pacific and Walvis Ridge in the South Atlantic (Bralower et al. 2002; Zachos et al. 2004). At Zumaia the calcareous nannofossil, planktonic and benthic foraminifera experienced a rapid and remarkable transformation (Bernaola et al. 2007). Calcareous nannofossil assemblage changes suggest a shift from relatively cool mesotrophic to warmer, more oligotrophic conditions. At the sea floor, the diversity of benthic foraminiferal assemblages, and the percentage of buliminids and of epifaunal suspension feeders decreased, whereas low food and opportunistic taxa (e.g. Haplophragmoides, Karrerulina and Recurvoides) show quantitative peaks at the clay-rich layer. These faunal changes are similar to those reported from other early Eocene deep-water disturbed environments during hyperthermal episodes, which possibly affected metabolic rates of deep-sea faunas (Thomas 2005). The calcareous nannofossil and planktonic foraminiferal turnovers started earlier than the benthic foraminiferal changes, indicating that the environmental change at the sea floor occurred after the changes in the surface waters. This pattern is consistent with a top-down warming of the ocean, and is similar to that reported by Bralower et al. (2002) for the Paleocene/Eocene thermal maximum. The Mid-Paleocene Biotic Event was short-lived: according to precession cycles the event lasted for ca. 52-53 kyr, with the core of the event representing ca. 10-11 kyr (Bernaola et al. 2007).

\section{Correlation to the historical stratotype areas}

\section{Base of Selandian}

In all outcrop sections in Denmark, the historical type region for the Selandian Stage, the Danian/Selandian boundary is marked by an unconformity with a variable number of biozones missing (Berggren 1971; Thomsen and Heilmann-Clausen 1985; see further review in Clemmensen and Thomsen 2005). It has therefore been difficult to determine the exact biostratigraphic position of the historical Danian/ Selandian boundary. These difficulties are exacerbated by the fact that the relevant index fossils used in international zonation schemes are rare or absent in the North Sea Basin (Berggren 1971; PerchNielsen 1979; King 1989; Thomsen and Heilmann-Clausen 1985; Varol 1989). The basal Selandian is generally correlated with 
planktonic foraminifera Zone P3a, while the uppermost Danian is referred to zones P1c or P2. These correlations are primarily based on a single occurrence of the planktonic foraminifera Morozovella angulata, index fossil of Zone P3a, in the Selandian at Copenhagen (Hansen 1968), and on the presence of Globoconusa daubjergensis in the uppermost Danian at most boundary localities. The highest occurrence of $G$. daubjergensis is widely used to approximate the top of Zone P1c (Olsson et al. 1999). Berggren et al. (1995, 2000) proposed to place the Danian/Selandian boundary (arbitrarily) at the P2/P3 zonal boundary correlating, approximately, with the middle of the calcareous nannofossil Zone NP4 and with the base of Chron C26r.

As predicted by Berggren (1971), younger Danian deposits which narrow the stratigraphic gap in the surface exposures are present in the subsurface of the Danish Basin. With the recovery of more continuous drill cores, including some from the Storebælt area, a gradual and complete succession of the Danian-Selandian transition could be studied in great detail. The succession of calcareous nannofossils in these cores, and particularly the appearance of Neochiastozygus perfectus close to the boundary, indicates that the Danian to Selandian change from limestone to clay occurs in the upper part of Zone NP4, close to the NP4/NP5 boundary (Thomsen and Heilmann-Clausen 1985; Thomsen 1994; von Salis Perch-Nielsen
1994; Clemmensen and Thomsen 2005). According to Berggren et al. (1995) the NP4/NP5 boundary is situated in the lower part of planktonic foraminifera Zone P3b, suggesting that the uppermost part of the Danian deposits in the Storebælt cores should be referred to Zone P3a. This agrees well with magnetostratigraphic studies of the Storebælt core 8604A showing that the Danian/Selandian boundary occurs a short distance up in Chron C26r (Ali et al. 1994).

The detailed sequence of calcareous nannofossil appearances and the magnetochronology at Zumaia suggest that the lithological change from the Aitzgorri Limestone Formation to the marls of the Itzurun Formation reflects the same paleogeographic event that caused the facies shift from Danian limestones to Selandian greensands, clays and marls in Denmark. Such a relationship was first proposed by Schmitz et al. (1998) who found the FO of $N$. perfectus in Zumaia close to the Aitzgorri Limestone/Itzurun formational boundary. Subsequent magnetostratigraphic and biostratigraphic studies referred to above give further support for such a correlation (e.g., Arenillas and Molina 2000; Dinarès-Turell et al. 2003, 2007; Arenillas et al. 2008; Bernaola et al. 2009). This included a relocation of the FO of $N$. perfectus to ca. $3 \mathrm{~m}$ below the Aitzgorri Limestone/Itzurun formational boundary (Fig. 16). Considering the strong regional evidence for a sea-level fall close to the NP4/NP5 boundary and in the lower part of magnetochron C26r both in Denmark and the Basque

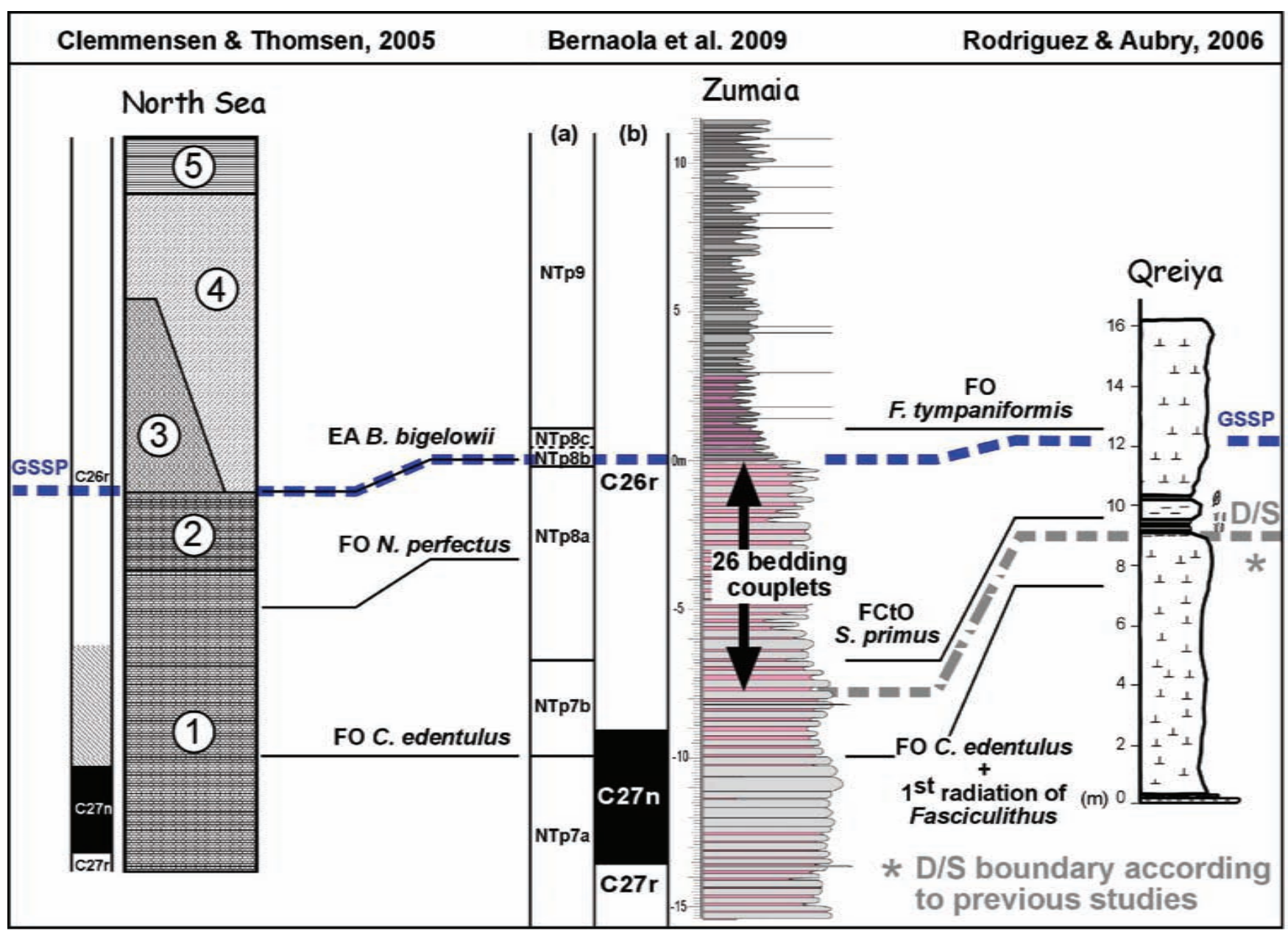

Figure 16. Biostratigraphic correlation of the Zumaia section with South Tethys (Qreiya) and Danish sections. (a) Calcareous nannofossil zones following the biozonation of Varol (1989), and (b) magnetostratigraphy after Dinarès-Turell et al. (2007). In North Sea log: $(1)=$ Bryozoa Limestone, (2)= Calcisiltite, (3)= Lellinge Greensand, (4)= Kerteminde Marl, (5)= AEbelø Formation. From Bernaola et al. (2009). The paleomagnetic data for the North Sea below the FO of $\mathrm{N}$. perfectus are of low quality and interpretations are uncertain. 
region (Knox 1994b; Baceta et al. 2007), and the fact that these regions are on the order of only $1500 \mathrm{~km}$ apart along the northeastern Atlantic margin, makes it likely that the same event has been registered.

These conclusions are further supported by a recent study of the Bidart and Loubieng outcrop sections in Aquitaine in southwestern France (Steurbaut and Sztrákos 2008). High-resolution calcareous nannofossil and foraminiferal investigations of these sections defined a time calibrated sequence of 47 bio-events within the DanianSelandian transition interval. The Danian/Selandian boundary, as originally defined in Denmark, is coeval with the lithologic change from limestone-dominated (Lasseube Formation) to marly sedimentation (Latapy Member of the Pont-Labau Formation) in southwestern Aquitaine. This horizon is also coeval with the Aitzgorri Limestone/Itzurun formational boundary at Zumaia. The Danian/ Selandian boundary in these areas is marked by the end of the acme of the nannofossil family Braarudosphaeraceae, possibly due to the disruption of fresh water influx related to climatic changes (Steurbaut and Sztrákos 2008; Bernaola et al. 2009). Studies of sections across the upper Danian and lower Selandian in Belgium indicate a similar sea-level history in relation to biostratigraphy as in Denmark and the Bay of Biscay region (Steurbaut and Sztrákos 2008). The sea-level changes therefore are either eustatic or related to large-scale tectonic events affecting the entire northwestern Europe. Cyclo- and magnetostratigraphic studies of the Loubieng section with correlations to Zumaia have further refined the stratigraphic scheme across the Danian-Selandian transition (Dinarès-Turell et al. 2010).

\section{Base of Thanetian}

Correlation to the historical type area is straightforward with the help of magnetostratigraphy (base of Chron C26n) and calcareous nannofossils (upper Zone NP6) (Aubry 1994; Hine 1994; Knox 1994a; Ali and Jolley 1996). The basal Thanetian in its original type area and its eastern prolongation in Belgium, as well as at Zumaia and in shallow-water sections in the Pyrenees reflects a major transgression, most likely related to the same eustatic or regional isostatic event (Knox 1994a,b; Steurbaut 1998; Pujalte et al. 1998a,b, 2000).

\section{Correlation to the Tethys}

In the southern Tethyan realm (e.g. Egypt, Tunisia, Israel) sedimentation conditions in the early and middle Paleocene are very different from the western European basins. Sections in the southern Tethys over this interval are typically characterized by monotonous brownish grey marls. One particular mid-Paleocene event level, represented either by an unconformity (in several Tunisian secions) or, as a prominent organic-rich bed, laminated and rich in fish debris (in several Egyptian sections), has been considered to possibly represent a Danian/Selandian boundary event (Steurbaut et al. 2000; Speijer 2000, 2003; Guasti et al. 2006; Van Itterbeeck et al. 2007; Obaidalla et al. 2009; Soliman and Obaidalla 2010). This level has previously been thought to correspond to the now defined base of the Selandian at Zumaia (e.g., Speijer 2003), but recent calcareous nannofossil and foraminiferal studies show that this event is ca. 400600 kyr older (Bernaola 2007; Steurbaut and Sztrákos 2008; Sprong et al. 2009) and is now termed the Latest Danian Event (Bornemann et al. 2009). In the Qreiya section the organic-rich layer occurs approximately $1 \mathrm{~m}$ above the FOs of $C$. edentulus and the small fasciculiths (Sprong et al. 2009). According to the cyclostratigraphic studies at Zumaia the FO of $C$. edentulus and the first continuous occurrence of Sphenolithus are 32 and 22, respectively, bedding couplets/precession cycles below the top of the Aitzgorri Limestone Formation (Bernaola 2007; Bernaola et al. 2009). Assuming a mean period of $21 \mathrm{kyr}$ for the precession cycles this means that these events are respectively 672 and $462 \mathrm{kyr}$ older than the top of the Danian limestones. At Qreiya the organic-rich layer is situated between these two events, and it is approximately 570 kyr older than the top of the Aitzgorri Limestone Formation in Zumaia and the Danian/Selandian boundary in the original type area of Denmark.

\section{Primary and secondary markers}

\section{Base of the Selandian}

The best event for global, marine correlation is the second radiation of the important calcareous nannofossil group, the fasciculiths (characterized by the first occurrence of Fasciculithus ulii s.s.). Cyclostratigraphy combined with magnetostratigraphy may also be crucial, for example, in correlation to continental sections. For regional marine correlation, at least in northwestern Europe, the end of the acme of the nannofossil family Braarudosphaeraceae together with the cessation of long-term carbonate deposition and evidence of sea-level fall can also be used.

\section{Base of the Thanetian}

The C26r/C26n magnetochron reversal is the best global correlation tool and can be applied to a variety of facies. Cyclostratigraphy together with the position of the Mid-Paleocene Biotic Event can be used for detailed marine correlation.

\section{Accessibility, conservation and protection}

Considering the exposure along the main "playa" of the town Zumaia accessibility to the GSSPs is optimal. There is even a hotel located on top of the cliff section (on the upper Thanetian part of the strata). The tilted nature of the strata allows excellent access along the beach at the same time as one ascends or descends through the geologic record. Access is limited during high tide and strong landward waves, however, both GSSPs are above the highest level where wave action normally erodes the cliffs, and there is no risk that the section will be lost because of erosion. The cliffs and the beach are major tourist attractions and the local community understands the value of preserving the area from exploitation that may damage the GSSPs. Moreover, the entire outcrop was protected by the Basque Government in February 2009 with the "Deba Zumaia Coastal Biotope", a declaration that guarantees the conservation of the outcrop. It is the first geological outcrop protected by law in the Basque Country. The management of the Biotope, including the Paleocene section, is in charge of the County Council of Gipuzkoa, which has created a particular "scientific management" to ensure the performance of the three main objectives of the natural reserve: the protection of the outcrop, the promotion and coordination of the scientific research and the popularization of the geological value of the area. There are no restrictions to sampling, but it is advisable to contact the scientific management of the section (flysch@gipuzkoa.net) to obtain the special 
permit that is required to work in the area. It is also important to note that there is an Interpretation Center in Zumaia called Algorri and that a complete program with geological guided excursions has been developed to promote the knowledge of the section among scholars and visitors. The Zumaia section also contains excellent records of the Cretaceous/Paleogene and Paleocene/Eocene boundaries, adding to its geological significance.

\section{Summary of selection procedures}

There was a general recognition early in the selection procedure that Zumaia would be one of the prime candidates for GSSPs, but nevertheless detailed or pilot studies have been made of a large number of sections mainly in the countries around the Mediterranean. The following alternative sections have been seriously considered: Gebel Aweina, Gebel Duwi and Gebel Qreiya in the Eastern Desert of Egypt (e.g., Charisi and Schmitz 1995, 1998; Speijer and Schmitz 1998; Speijer 2000, 2003; Sprong et al. 2009), Ben Gurion in Israel (Schmitz et al. 1997b; Charisi and Schmitz 1998), the Sidi Nasseur and Ain Settara sections near Kalaat Senan in Tunisia (Steurbaut et al. 2000; Guasti et al. 2006; Van Itterbeeck et al. 2007; Sprong et al. 2009), Bottaccione Gorge and Contessa Highway in Italy (Corfield et al. 1991), and Caravaca in Spain (Arenillas and Molina 1997). In its final stage the selection procedure was narrowed down to a comparison of two sections, Zumaia, and the Qreiya section in the Eastern Desert of Egypt. Because of their excellent records both sections have been studied in detail by several groups and considerable data exist. A detailed profile across the Qreiya section was sampled by B. Schmitz, R. Knox, N. Obaidallah and M. Soliman in 2004. These samples were distributed within the Paleocene Working Group and have resulted in several detailed studies (e.g., Bernaola 2007; Monechi and Reale 2007; Orue-Etxebarria et al. 2007a,b; Rodríguez and Aubry 2007). Stratigraphy and paleoenvironments were also intensively studied in several parallel sections at Gebel Qreiya (e.g., Speijer 2000, 2003; Bornemann et al. 2009; Sprong et al. 2009).

One major advantage of Zumaia is its position intermediate between the North Sea (or boreal) region, where the original stratotype sections for the Selandian and Thanetian were defined, and the more southerly Tethys region, e.g. Egypt, Tunisia and South Spain (Schmitz et al. 1998). The Zumaia section contains faunal and floral elements representative of both regions and this facilitates correlation between the North Sea and the rest of the world. During the Paleocene the Zumaia site appears to have been affected by the same sea-level and lithology changes as other northwestern European sites. Placing the GSSP for the base of the Selandian at the shift from limestone to marl in the upper NP4 Zone pays homage to Alfred Rosenkrantz's original definition of the Selandian (1924) at the shift from limestone to grey marl in the Danish Basin, because most likely the change in lithology at Zumaia registers the same regional event. The limestone/marl shift of Zumaia has also been identified in the Loubieng section in Aquitaine (SW France) (Steurbaut and Sztrákos 2008). Both sections are marked by a common depositional history, as shown by the almost identical stratal succession and sequence of bio-events. Zumaia excels through its better and more permanent accessibility of the outcrop (coastal section versus quarry) and the wider gamut of scientific information (presence of magnetostratigraphic and cyclostratigraphic studies), but Loubieng is an excellent auxiliary section. The Zumaia section is also superior relative to Qreiya because of its much better accessibility. A visit to the Qreiya section requires a small expedition with at least

\begin{tabular}{|c|c|}
\hline $\begin{array}{l}\text { Prerequisites to be fulfilled by a } \\
\text { chronostratigraphic type-section }\end{array}$ & Zumaia \\
\hline $\begin{array}{l}\text { a) Exposure over an adequate } \\
\text { thickness of sediments }\end{array}$ & The whole Paleocene is exposed \\
\hline b) Continuous sedimentation & No gap detected \\
\hline e) Rate of sedimentation & $1,5 \mathrm{~cm} / \mathrm{kyr}$ (Paleocene $\approx 150 \mathrm{~m}$ ) \\
\hline $\begin{array}{l}\text { d) Freedom from metamorphism } \\
\text { and strong diagenetic alteration }\end{array}$ & YES \\
\hline $\begin{array}{l}\text { e) Abundance and diversity of well } \\
\text { preserved fossils }\end{array}$ & YES \\
\hline $\begin{array}{l}\text { f) Freedom from vertical facies } \\
\text { changes }\end{array}$ & NO \\
\hline $\begin{array}{l}\text { g) Favorable facies for long range } \\
\text { biostratigraphic correlation }\end{array}$ & $\begin{array}{l}\text { Tethys YES } \\
\text { Atlantic Ocean YES } \\
\text { North Sea/type area YES }\end{array}$ \\
\hline h) Amenability to radiometric dating & $\begin{array}{l}\text { We don't know, but there is the possibility to } \\
\text { absolute dating with cyclostratigraphy }\end{array}$ \\
\hline $\begin{array}{l}\text { i) Amenability to } \\
\text { magnetostratigraphy }\end{array}$ & YES (Dinarès-Turell el al, 2003; 2007, 2010) \\
\hline j) Amenability to chemostratigraphy & YES \\
\hline k) Accessibility & Excellent \\
\hline 1) Free access & $\begin{array}{l}\text { Yes. The outcrop is included into the Deba } \\
\text { Zumaia Coastal Biotope, which is willing to } \\
\text { colaborate and promote the scientific activity } \\
\text { in the area. An application form can be obtained } \\
\text { from flysch@gipuzkoa.net, which must be filled } \\
\text { to obtain permission to work in the section. }\end{array}$ \\
\hline $\begin{array}{l}\text { m) Permanent preservation of the } \\
\text { site }\end{array}$ & $\begin{array}{l}\text { Yes. The section is located into the reserve } \\
\text { area of the Biotope and therefore it is protected } \\
\text { by law. The local goverment understands its } \\
\text { value and makes an important effort to } \\
\text { preserve it. }\end{array}$ \\
\hline
\end{tabular}

Figure 17. Summary of evaluation of the Zumaia section for holding the Selandian and Thanetian GSSPS in relation to the recommendations by the International Commission on Stratigraphy.

two jeeps plus desert permits. The Zumaia section is also more expanded than the Qreiya section, at least across the Danian-Selandian transition. An important consideration is the fact that high-resolution cyclostratigraphy and good magnetostratigraphy exist for Zumaia, whereas these parameters cannot be used at Qreiya. This is a very strong argument in favor of Zumaia. Preservation of foraminifera and calcareous nannofossils is superior at Qreiya relative to Zumaia, but preservation at Zumaia is still sufficient for establishing a highresolution biostratigraphy. At Zumaia correlations and comparative studies can be made with nearby coeval sediment sections representing a wide range of facies and environments, including base of slope apron, inner and outer shelf, deep-sea channels and even continental facies in the Tremp Basin to the southeast (Schmitz and Pujalte 2003). This correlation potential opens the prospect for detailed temporal and spatial reconstructions of sea-level changes at the Danian/ Selandian and Selandian/Thanetian boundaries. At Qreiya there is also substantial correlation potential, but the spectrum of paleoenvironments is not as wide as in the Pyrenean region. At the final meeting of the Paleocene Working Group, held in Zumaia in June 2007, these issues were discussed in detail, and based on evaluations of extensive and detailed data sets the Zumaia section was unanimously considered the most suitable section to host the 
GSSPs for the Selandian and Thanetian stages. The working group carefully evaluated the standing of the Zumaia section in relation to the requirements for a GSSP according to the International Commission on Stratigraphy, and found that Zumaia is close to ideal for placing the GSSPs there (see further compilation in Fig. 17). The International Union of Geological Sciences ratified the proposed GSSPs for the Selandian and Thanetian stages at Zumaia on September 23, 2008.

\section{References}

Adatte, T., Bolle, M.P., de Kaenel, E., Gawenda, P., Winkler, W. and von Salis, K., 2000. Climatic evolution from Paleocene to earliest Eocene inferred from clay-minerals: a transect from northern Spain (Zumaya) to southern (Spain, Tunisia) and southeastern Tethys margins (Israel, Negev). GFF, v. 122, pp. 7-8.

Agnini, C., Fornaciari, E., Raffi, I., Rio, D., Röhl, U. and Westerhold, T., 2007. Evolution of middle Paleocene through early Eocene calcareous nannofossil (ODP Site 1262, Walvis Ridge, southern Atlantic Ocean). Marine Micropaleontology, v. 64, pp. 215-248.

Ali, J. R. and Jolley, D. W., 1996. Chronostratigraphic framework for the Thanetian and lower Ypresian deposits of SE England. Geological Society of London Special Publication, v. 101, pp. 129-144.

Ali, J. R., Heilmann-Clausen, C., Thomsen, E. and Abrahamsen, N., 1994. Magnetostratigraphy of the type Selandian: preliminary results: GFF, v. 116, pp. 43.

Alvarez, W., Alvarez, L. W., Asaro, F. and Michel, H. V., 1982. Current status of the impact theory for the terminal Cretaceous extinction. Geological Society of America Special Paper, v. 190, pp. 305315 .

Apellaniz, E., 1998. Los foraminíferos planctónicos en el tránsito Cretácico-Terciario: análisis de cuatro secciones en depósitos de cuenca profunda de la Región Vasco-Cantábrica. Tesis doctoral. Universidad del País Vasco, 390 p.

Apellaniz, E., Lamolda, M. A. and Orue-Etxebarria, X., 1983. Posición estratigráfica de las "Calizas del Danés", País Vasco. Revista Española de Micropaleontología, v. 15, pp. 447-455.

Arenillas, I. and Molina, E., 1997, Análisis cuantitativo de los foraminíferos planctónicos del Paleoceno de Caravaca (Cordilleras Béticas): Cronoestratigrafía, bioestratigrafía y evolución de las asociaciones. Revista Española de Paleontología, v. 12 , pp. 207-232.

Arenillas, I. and Molina, E., 2000. Reconstrucción paleoambiental con foraminíferos planctónicos y cronoestratigrafía del tránsito Paleoceno-Eoceno de Zumaya (Guipúzcoa). Revista Española de Micropaleontología, v. 32, pp. 283-300.

Arenillas, I., Arz, J. A., and Molina, E., 1998. El límite Cretácico/ Terciario de Zumaya, Osinaga y Músquiz (Pirineos): control bioestratigráfico y cuantitativo de hiatos con foraminíferos planctónicos. Revista de la Sociedad Geológica de España, v. 11, pp. 127-138.

Arenillas, I., Arz, J. A. and Molina, E., 2004. A new high-resolution planktic foraminiferal zonation and subzonation for the lower Danian. Lethaia, v. 37, pp. 79-95.

Arenillas, I., Molina, E., Ortiz, S. and Schmitz, B., 2008. Foraminiferal and $\delta^{13} \mathrm{C}$ isotopic event-stratigraphy across the Danian-Selandian transition at Zumaya (northern Spain): chronostratigraphic implications. Terra Nova, v. 20, pp. 38-44.
Arz, J. A., Arenillas, I. and Molina, E., 1999. Extinción de foraminíferos planctónicos en el tránsito Cretácico-Terciario de Zumaya (Guipúzcoa): supervivencia o relaboración? Revista Española de Micropaleontología, v. 31, pp. 297-304.

Aubry, M.-P., 1994. The Thanetian Stage in NW Europe and its significance in terms of global events. GFF, v. 116, pp. 43-44.

Aubry, M.-P., Ouda, K., Dupuis, C., Berggren, W. A., Van Couvering, J. A. and the Members of the Working Group on the Paleocene/ Eocene Boundary, 2007. Global Standard Stratotype-section and Point (GSSP) for the base of the Eocene Series in the Dababiya section (Egypt). Episodes, v. 30, pp. 271-286.

Baceta, J. I., 1996. El Maastrichiense superior, Paleoceno e Ilerdiense inferior de la Región Vasco-Cantábrica: Secuencias Deposicionales, Facies y Evolución Paleogeográfica. Tesis Doctoral. Universidad del País Vasco, 372 p.

Baceta, J. I., Wright, V. P. and Pujalte, V., 2001. Palaeo-mixing zone karst features from Paleocene carbonates of northern Spain: criteria for recognizing a potentially widespread but rarely documented diagenetic system. Sedimentary Geology, v. 139, pp. 205- 216.

Baceta, J. I., Pujalte, V., Serra-Kiel, J., Robador, A. and OrueEtxebarria, X., 2004. El Maastrichtiense final, Paleoceno e Ilerdiense inferior de la Cordillera Pirenaica. In: Vera, J.A. (Ed.), Geología de España. Sociedad Geológica de España-Instituto Geológico y Minero de España, Madrid, pp. 308-313.

Baceta, J. I., Pujalte V. and Bernaola, G., 2005. Paleocene coralagal reefs of the Western Pyrenean basin, northern Spain: New evidence supporting an earliest Paleogene recovery of reefal ecosystems. Palaeogeography, Palaeoclimatology, Palaeoecology, v. 224, pp. 117-143.

Baceta, J. I., Bernaola, G. and Arostegi, J., 2006. The mid-Paleocene interval at Zumaia. 4.2 Lithostratigraphy. In: Bernaola, G., Baceta, J. I., Payros, A., Orue-Etxebarria, X., Apellaniz, E. (Eds.). The Paleocene and lower Eocene of the Zumaia section (Basque Basin). Climate and Biota of the Early Paleogene 2006. Post Conference Field Trip Guidebook, Bilbao, pp. 38-42.

Baceta, J. I., Wright, V. P., Beavington-Penney, S. J. and Pujalte, V., 2007. Palaeohydrological control of palaeokarst macro-porosity genesis during a major sea-level lowstand: Danian of the UrbasaAndia plateau, Navarra, North Spain. Sedimentary Geology, v. 199, pp. 141-169.

Berggren, W. A., 1971. Tertiary boundaries and correlations. In: Funnell, B. M. and Riedel, W. R. (Eds.). The Micropaleontology of the Oceans. Cambridge University Press, pp. 693-809.

Berggren, W. A., 1994. In defense of the Selandian Age/Stage. GFF, v. 116, pp. 44-46.

Berggren, W. A. and Aubert, J., 1975. Paleocene benthonic foraminiferal biostratigraphy, paleobiogeography and paleoecology of Atlantic-Tethyan regions: Midway-type fauna. Palaeogeography, Palaeoclimatology, Palaeoecology, v. 18, pp. 73-192.

Berggren, W. A. and Pearson, P. N., 2005. A revised tropical to subtropical Paleogene planktonic foraminiferal zonation. Journal of Foraminiferal Research, v. 35, pp. 279-298.

Berggren, W. A., Kent, D. V., Swisher, III, C. C. and Aubry M.-P., 1995. A revised Cenozoic geochronology and chronostratigraphy. SEPM Special Publication, v. 54, pp. 129-212.

Berggren, W. A., Aubry, M.-P., van Fossen, M., Kent, D. V., Norris, R. D. and Quillévéré, F., 2000. Integrated Paleocene calcareous 
plankton magnetobiochronology and stable isotope stratigraphy: DSDP Site 384 (NW Atlantic Ocean). Palaeogeography, Palaeoclimatology, Palaeoecology, v. 159, pp. 1-51.

Bernaola, G., 2002. Los nannofósiles calcáreos del Paleoceno en el Dominio Pirenaico. Bioestratigrafía, cronoestratigrafía y paleoecología. Tesis Doctoral, Universidad del País Vasco, $445 \mathrm{p}$.

Bernaola, G., 2007. New high-resolution calcareous nannofossil analysis across the Danian-Selandian transition at the Zumaya section: Comparison with South Tethys and Danish sections. International Workshop of the Paleocene Working Group, Abstract Volume. Zumaia, Basque Country, pp. 13-17.

Bernaola, G. and Nuño-Arana, Y., 2006. Calcareous nannofossil assemblages across the mid-Paleocene. In: Bernaola, G., Baceta, J. I., Payros, A., Orue-Etxebarria, X., Apellaniz, E. (Eds.). The Paleocene and lower Eocene of the Zumaia section (Basque Basin). Climate and Biota of the Early Paleogene 2006. Post Conference Field Trip Guidebook, Bilbao, pp. 44-46.

Bernaola, G., Baceta, J. I., Orue-Etxebarria, X., Alegret, L., MartínRubio, M., Arostegui, J. and Dinarès-Turell, J., 2007. Evidence of an abrupt environmental disruption during the mid-Paleocene biotic event (Zumaia section, western Pyrenees). Geological Society of America Bulletin, v. 119, pp. 785-795.

Bernaola, G., Martín-Rubio, M. and Baceta, J. I., 2009. New high resolution calcareous nannofossil analysis across the Danian/ Selandian transition at the Zumaia section: comparison with South Tethys and Danish sections. Geologica Acta, v. 7, pp. 79-92.

Bignot, G., Curry, D. and Pomerol, C., 1997. The resistible rise of the Selandian. Neues Jahrbuch für Geologie und Paläontologie Monatshefte, v. 1997, pp. 114-128.

Bralower, T. J., Premoli Silva, I., Malone, M. J. and 24 others, 2002. Proceedings of the Ocean Drilling Program Initial Reports, Leg 198, http://www-odp.tamu.edu/ publications/198_IR/198ir.htm.

Bornemann, A., Schulte, P., Sprong, J., Steurbaut, E., Youssef, M. and Speijer, R.P., 2009. Latest Danian carbon isotope anomaly and associated environmental change in the southern Tethys (Nile Basin, Egypt). Journal of the Geological Society of London, v. 166, pp. 1135-1142.

Caballero, F., 2007. Análisis micropaleontológico de los límites Cretácico/Terciario, Daniense/Selandiense y Paleoceno/Eoceno en la Cuenca Vasco-Cantábrica, a través de foraminíferos planctónicos. Tesis Doctoral, Universidad del País Vasco, 519 pp.

Canudo, J. I. and Molina, E., 1992. Planktic foraminiferal faunal turnover and bio-chronostratigraphy of the Paleocene/Eocene boundary at Zumaya (Northern Spain). Revista de la Sociedad Geológica de España, v. 5, pp. 145-157.

Canudo, J. L., Keller, G., Molina, E. and Ortiz, N., 1995. Planktic foraminiferal turnover and $\delta^{13} \mathrm{C}$ isotopes across the PaleoceneEocene transition at Caravaca and Zumaya, Spain. Palaeogeography, Palaeoclimatology, Palaeoecology, v. 114, pp. $75-100$.

Charisi, S. D. and Schmitz B., 1995. Stable $\left(\delta^{13} \mathrm{C}, \delta^{18} \mathrm{O}\right)$ and strontium $\left({ }^{87} \mathrm{Sr} /{ }^{86} \mathrm{Sr}\right)$ isotopes through the Paleocene at Gebel Aweina, eastern Tethyan region. Palaeogeography, Palaeoclimatology, Palaeoecology, v. 116, pp. 103-130.

Charisi, S.D. and Schmitz, B., 1998. Paleocene to early Eocene paleoceanography of the Middle East: $\delta^{13} \mathrm{C}$ and $\delta^{18} \mathrm{O}$ isotopes from foraminiferal calcite. Paleoceanography, v. 13, pp. 106-118.
Clemmensen, A. and Thomsen, E., 2005. Paleoenvironmental changes across the Danian/Selandian boundary in the North Sea Basin. Palaeogeography, Palaeoclimatology, Palaeoecology, v. 219, pp. 351-394.

Corfield, R. M., 1994. Palaeocene oceans and climate: An isotopic perspective. Earth-Science Reviews, v. 37, pp. 225-252.

Corfield, R. M, Cartlidge, J. E., Premoli-Silva, I. and Housley, R. A., 1991. Oxygen and carbon isotope stratigraphy of the Paleogene and Cretaceous limestones in the Bottaccione Gorge and the Contessa Highway sections, Umbria, Italy. Terra Nova, v. 3, pp. 414-422

Dinarès-Turell, J., Baceta, J. I., Pujalte, V., Orue-Etxebarria, X. and Bernaola, G., 2002. Magnetostratigraphic and cyclostratigraphic calibration of a prospective Palaeocene-Eocene stratotype at Zumaia (Basque Basin, northern Spain). Terra Nova, v. 14, pp. 371-378.

Dinarès-Turell, J., Baceta, J. I., Pujalte, V., Orue-Etxebarria, X., Bernaola, G. and Lorito, S., 2003. Untangling the Palaeocene climatic rhythm: an astronomically calibrated Early Paleocene magnetostratigraphy and biostratigraphy at Zumaia (Basque basin, northern Spain). Earth and Planetary Science Letters, v. 216, pp. 483-500.

Dinarès-Turell, J., Baceta, J. I., Bernaola, G., Orue-Etxebarria, X. and Pujalte, V., 2007. Closing the Mid-Palaeocene gap: Toward a complete astronomically tuned Palaeocene Epoch and Selandian and Thanetian GSSPs at Zumaia (Basque Basin, W. Pyrenees). Earth and Planetary Science Letters, v. 262, pp. 450-467.

Dinarès-Turell, J., Stoykova, K., Baceta, J.I., Ivanov, M. and Pujalte, V., 2010. High-resolution intra- and interbasinal correlation of the Danian-Selandian transition (Early Paleocene): The Bjala section (Bulgaria) and the Selandian GSSP at Zumaia (Spain). Palaeogeography, Palaeoclimatology, Palaeoecology, v. 297, pp. 511-533.

Dollfus, G. F., 1880. Essai sur l'extension des terrains tertiaires dans le basin anglo-parisien. Bulletin de la Société Géologique de Normandie, v. 6, pp. 584-605.

Gómez de Llarena, J., 1946. Revisión de algunos datos paleontológicos del Flysch cretáceo y nummulítico de Guipúzcoa. Instituto Geológico y Minero de España, Notas y Comunicaciones, v. 15 , pp. 113-165.

Gorostidi, A., 1993. Nanofósiles calcareous y eventos del Cretácico Medio-Superior de la Cuenca Vasco-Cantábrica. Tesis Doctoral. Universidad del País Vasco, 331 pp.

Guasti, E., Speijer, R. P., Brinkhuis, H., Smit, J. and Steurbaut, E., 2006. Paleoenvironmental change at the Danian-Selandian transition in Tunisia: Foraminifera, organic-walled dinoflagellate cyst and calcareous nannofossil records. Marine Micropaleontology, v. 59, pp. 210-229.

Hansen, H. J., 1968. On the biostratigraphical age of the lower Selandian of Denmark. Meddelelser fra Dansk Geologisk Forening, v. 18, pp. 277-284.

Heilmann-Clausen, C., 1985. Dinoflagellate stratigraphy of the uppermost Danian to Ypresian in the Viborg 1 borehole, central Jylland, Denmark. Danmarks Geologiske Undersøgelse, v. A7, pp. 1-89.

Heilmann-Clausen, C., 1994. Review of Paleocene dinoflagellates from the North Sea region. GFF, v. 116, pp. 51-53.

Heilmann-Clausen, C., 2007. Dinocysts from an expanded section of the Selandian-Thanetian transition: the Rødbyhavn-1 borehole, 
SE Denmark. International Workshop of the Paleocene Working Group, Abstract Volume. Zumaia, Basque Country, pp. 2627.

Hilgen, F. J., Kuiper, K. F. and Lourens, L. J., 2010. Evaluation of the astronomical time scale for the Paleocene and earliest Eocene. Earth and Planetary Science Letters, v. 300, p. 139-151.

Hillebrandt, A. von, 1965. Foraminiferen-Stratigraphie in Alttertiär von Zumaya (Provinz Guipúzcoa, NW Spanien) und ein Vergleich mit anderen Tethys-Gebieten. Bayerische Akademie der Wissenschaften, Abhandlungen der Mathematisch-Naturwissenschaftlichen Klasse, v. 123, pp. 1-62

Hine, N. M., 1994. Calcareous nannoplankton assemblages from the Thanet Formation in the Bradwell Borehole, Essex, England. GFF, v. 116 , pp. 54-55.

Jenkins, D. G. and Luterbacher, H.-P., 1992. Paleogene stages and their boundaries (Introductory remarks). Neues Jahrbuch für Geologie und Paläontologie, Abhandlungen, v. 186, pp. 1-5.

Kapellos, C. H., 1974. Ueber das Nannoplankton im Alttertiär des Profils von Zumaya-Guetaria (Provinz Guipúzcoa, Nordspanien). Eclogae geologica Helvetica, v. 67, pp. 435-444.

King, C., 1989. Cenozoic of the North Sea. In: Jenkins, D. G. and Murray, J. W. (Eds.). Stratigraphical Atlas of Fossil Foraminifera, Second Edition. Ellis Horwood Limited Publishers, Chichester, pp. 418-489.

Knox, R. W. O'B., 1994a. The age and regional context of the Thanetian stratotype sections of SE England. GFF, v. 116, pp. 55-56.

Knox, R. W. O'B., 1994b. From regional stage to standard stage: implications for the historical Paleogene stratotypes of NW Europe. GFF, v. 116, pp. 56-57.

Knox, R. W. O’B., 1998. Kaolinite influx within Paleocene/Eocene boundary strata of western Europe. Newsletter on Stratigraphy, v. 36, pp. 49-53.

Kuhnt, W. and Kaminski, M. A., 1997. Cenomanian to lower Eocene deep-water agglutinated foraminifera from the Zumaya section, northern Spain. Annales Societatis Geologorum Poloniae, v. 67, pp. 257-270.

Kuiper, K. F., Deino, A., Hilgen, F. J., Krijgsman, W., Renne, P. R., and Wijbrans, J. R., 2008. Synchronizing rock clocks of Earth history. Science, v. 320, pp. 500-504.

Laskar, J., Robutel, P., Joutel, F., Gastineau, M., Correia, A. and Levrard, B., 2004. A long-term numerical solution for the insolation quantities of the Earth. Astronomy and Astrophysics, v. 428, pp. 261-285.

Lourens, J. L., Hilgen, F. J., Laskar, J., Shackleton, N. J. and Wilson, D., 2004. The Neogene Period. In: A Geologic Timescale 2004. Gradstein, F. M., Ogg, J. G., and Smith, A. G. (Eds.), Cambridge University Press, pp. 409-440.

Luterbacher, H. P., Ali, J. R., Brinkhuis, H., Gradstein, F. M., Hooker, J. J., Monechi, S., Ogg, J. G., Powell, J., Röhl, U., Sanfilippo, A. and Schmitz, B., 2004. The Paleogene Period. In: A Geologic Timescale 2004. Gradstein, F. M., Ogg, J. G., and Smith, A. G. (Eds.), Cambridge University Press, pp. 384-408.

Martini, E., 1971. Standard Tertiary and Quaternary calcareous nannoplankton zonation. In: Farinacci, A. (Ed.). Proceedings of the Second Planktonic Conference, Rome 1970, Editizione Technoscienza, Rome, pp. 739-785.

Molina, E., Arenillas, I. and Arz, J. A., 1998. Mass extinction in planktic foraminifera at the Cretaceous/Tertiary boundary in subtropical and temperate latitudes. Bulletin de la Société géologique de France, v. 169, pp. 351-363.

Molina, E., Arenillas, I. and Pardo, A., 1999. High-resolution planktic foraminiferal biostratigraphy and correlation across the Paleocene/ Eocene boundary in the Tethys. Bulletin de la Société géologique de France, v. 170, pp. 521-531.

Molina, E., Alegret L., Arenillas I., Arz, J. A., Gallala, N., Hardenbol, J., von Salis, K., Steurbaut E., Vandenberghe, N. and ZaghbibTurki, D., 2006. The Global Boundary Stratotype Section and Point for the base of the Danian Stage (Paleocene, Paleogene, "Tertiary", Cenozoic) at El Kef, Tunisia - Original definition and revision. Episodes, v. 29, pp. 263-273.

Molina, E., Alegret, L., Arenillas, I., Arz, J.A., Gallala, N., GrajalesNishimura, M., Murillo-Muñeton, G. and Zaghbib-Turki, D., 2009. The Global Boundary Stratotype Section and Point for the base of the Danian Stage (Paleocene, Paleogene, "Tertiary", Cenozoic): auxiliary sections and correlation. Episodes, v. 32, pp. 84-95.

Monechi, S. and Reale,, V., 2007. Danian-Selandian evolutionary trend of Fasciculithus at ODP Site 1262, comparison with the Qreiya (Egypt) and Zumaia (Spain) sections. International Workshop of the Paleocene Working Group, Abstract Volume. Zumaia, Basque Country, pp. 28-29.

Nielsen, S. B., Thomsen, E., Hansen, D. L. and Clausen, O. R., 2005. Platewide stress relaxation explains European Palaeocene basin inversions. Nature, v. 435, pp. 195-198.

Nielsen, S. B., Stephenson, R. and Thomsen, E., 2007. Dynamics of Mid-Palaeocene North Atlantic rifting linked with European intraplate deformations. Nature, v. 450, pp. 1071-1074.

Obaidalla, N. A., El-Dawy, M. H. and Kassab, A. S., 2009. Biostratigraphy and paleoenvironment of the Danian/Selandian (D/S) transition in the Southern Tethys: A case study from north Eastern Desert, Egypt. Journal of African Earth Sciences, v. 53, pp. 1-15.

Olsson, R. K., Hemleben, C., Berggren, W. A. and Huber, B. T., 1999. Atlas of Paleocene planktonic foraminifera. Smithsonian Contributions in Paleobiology, v. 85, pp. 1-252.

Ortiz, N., 1995. Differential patterns of benthic foraminiferal extinctions near the Paleocene/Eocene boundary in the North Atlantic and the western Tethys. Marine Micropaleontology, v. 136, pp. 17-30.

Orue-Etxebarria, X., Bernaola, G., Baceta, J.I., Angori, E., Caballero, F., Monechi, S., Pujalte, V., Dinarès-Turell, J., Apellaniz, E. and Payros, A., 2004. New constraints on the evolution of planktic foraminifers and calcareous nannofossils across the Paleocene/ Eocene boundary interval: the Zumaia section revisited. Neues Jahrbuch für Geologie und Paläontologie, Abhandlungen, v. 234, pp. 223-259.

Orue-Etxebarria, X., Apellaniz, E. and Caballero, F., 2007a. Discrepancies in planktic foraminifera biostratigraphies across the Danian-Selandian transition at Zumaia: Not poor preservation, but taxonomic different concepts. International Workshop of the Paleocene Working Group, Abstract Volume. Zumaia, Basque Country, pp. 30-32.

Orue-Etxebarria, X., Alegret, L., Apellaniz, E., Arenillas, I., Baceta, J. I., Bernaola, G., Caballero, F., Dinarès-Turell, J., Martín-Rubio, M., Molina, E., Ortiz, S., Pujalte, V. and Schmitz, B., 2007b. The Zumaia section: a robust candidate for the placement of the Danian/Selandian and Selandian/Thanetian boundaries. 
International Workshop of the Paleocene Working Group, Abstracts Volume. Zumaia, Basque Country, pp. 33-35.

Orue-Etxebarria, X., Apellaniz, E., Ortiz, S., Pujalte, V. and Caballero, F., 2010. New foraminiferal criteria to pinpoint the newly defined GSSP for the Mid-Paleocene Selandian Stage in the Zumaia Section (Basque Country). International Symposium on Foraminifera (Forams 2010). Abstract volume with program, pp. 151.

Pedersen, G. K. and Surlyk, F., 1983. The Fur Formation, a late Paleocene ash-bearing diatomite from northern Denmark. Bulletin of the Geological Society of Denmark, v. 32, pp. 43-65.

Perch-Nielsen, K., 1979. Calcareous nannofossil zonation at the Cretaceous/Tertiary boundary in Denmark. In: Birkelund, T. and Bromley, R. G. (Eds.). Proceedings Cretaceous/Tertiary Boundary Events Symposium, vol. 1. University of Copenhagen, Copenhagen, pp. 115-135.

Perch-Nielsen, K. and Hansen, J. M., 1981. Selandian. In: Pomerol, C. (Ed.). Stratotypes of Paleogene stages. Mémoire hors série 2 du Bulletin d'information des géologues du Bassin de Paris, pp. 215-230.

Pujalte, V., Baceta, J. I., Dinarès-Turell, J., Orue-Etxebarria, X., Parès, J. M. and Payros, A., 1995. Biostratigraphic and magnetostratigraphic intercalibration of late Maastrichtian and Paleocene depositional sequences from the deep-water Basque basin, W. Pyrenees, Spain. Earth and Planetary Science Letters, v. 136, pp. 17-30.

Pujalte, V., Baceta, J. I., Orue-Etxebarria, X. and Payros, A., 1998a: Paleocene strata of the Basque Country, W Pyrenees, N Spain: Facies and sequence development in a deep-water, starved basin: In: Gracianski et al. (Ed.). Mesozoic and Cenozoic Sequence Stratigraphy of European Basins. Special Publications of the SEPM, v. 60, pp. 311-325.

Pujalte, V., Baceta, J. I., Apellaniz, E., Orue-Etxebarria, X., Payros, A. and Serra-Kiel, J., 1998b. Paleocene of the Pyrenees and the North Sea Basin: differences and similarities. Newsletter on Stratigraphy, v. 36, pp. 43-47.

Pujalte, V., Robles, S., Orue-Etxebarria, X., Baceta, J. I., Payros, A. and Larruzea, I. F., 2000. Uppermost Cretaceous-middle Eocene strata of the Basque-Cantabrian region and western Pyrenees: a sequence stratigraphic perspective. Revista de la Sociedad Geologica de España, v. 13, pp. 191- 211.

Quillévéré, F., Aubry, M.-P., Norris, R. D. and Berggren W. A., 2002. Paleocene oceanography of the eastern subtropical Indian Ocean: An integrated magnetobiostratigraphic and stable isotope study of ODP Hole 761B (Wombat Plateau). Palaeogeography, Palaeoclimatology, Palaeoecology, v. 184, pp. 371-405.

Renevier, E., 1873. Tableau des terrains sédimentaires formés pendant les époques de la phase organique du globe terrestre. Bulletin de la Société Vaudoise des Sciences Naturelles, Laussane, v. 12, pp. 218-252.

Rodríguez, O. M. and Aubry, M.-P., 2007. Lower to middle (DanianSelandian) Paleocene calcareous nannofossil stratigraphy of the Qreiya section (Egypt). International Workshop of the Paleocene Working Group, Abstract Volume. Zumaia, Basque Country, pp. 40.

Rosenkrantz, A., 1924. De københavnske Grønsandslag og deres Placering i den danske Lagrække. Med et Skema over det danske Paleocæn. Meddelelser fra Dansk geologisk Forening, v. 6, pp. 22-39.
Salis Perch-Nielsen, K. von, 1994. Neogene and Paleogene calcareous nannofossils from the Harre borehole, Denmark. In: Nielsen, O.B. (Ed.). Lithostratigraphy and Biostratigraphy of the Tertiary Sequence from the Harre Borehole, Denmark. Aarhus Geoscience, v. 1, pp. 45-51.

Schmitz, B., 1994. The Paleocene Epoch - stratigraphy, global change and events. GFF, v. 116, pp. 39-41.

Schmitz, B. and Pujalte, V., 2003. Sea-level, humidity and land erosion records across the initial Eocene thermal maximum in a continental-marine transect in northern Spain. Geology, v. 31, pp. 689-692.

Schmitz, B., Asaro, F., Molina, E., Monechi, S., von Salis, K. and Speijer, R. P., 1997a. High-resolution iridium, $\delta^{13} \mathrm{C}, \delta^{18} \mathrm{O}$, foraminifera and nannofossil profiles across the latest Paleocene benthic extinction event at Zumaya, Spain. Palaeogeography, Palaeoclimatology, Palaeoecology, v. 133, pp. 49-68.

Schmitz, B., Charisi, S. D., Thompson, E. I. and Speijer, R. P., 1997 b. Barium, $\mathrm{SiO}_{2}$-excess and $\mathrm{P}_{2} \mathrm{O}_{5}$ as proxies of biological productivity in the Middle East during the Paleocene and the latest Paleocene benthic extinction event. Terra Nova, v. 9, pp. 95-99.

Schmitz, B., Molina, E. and von Salis, K., 1998. The Zumaya section in Spain: A possible global stratotype section for the Selandian and Thanetian stages. Newsletters on Stratigraphy, v. 36, pp. 3542.

Schmitz, B., Pujalte, V. and Núñez-Betelu, K., 2001. Climate and sea-level perturbations during the Initial Eocene Thermal Maximum: evidence from siliciclastic units in the Basque Basin (Ermua, Zumaia and Trabakua Pass), northern Spain. Palaeogeography, Palaeoclimatology, Palaeoecology, v. 165 pp. 299320.

Seilacher, A., 1962. Paleontological studies on turbidite sedimentation and erosion. Journal of Geology, v. 70, pp. 227-234.

Smit, J. and Ten Kate, W. G., 1982. Trace-element patterns at the Cretaceous/Tertiary boundary: consequences of a large impact. Cretaceous Research, v. 3, pp. 307-332.

Soliman, M. F. and Obaidalla, N. A., 2010. Danian-Selandian transition at Gabal el-Qreiya section, Nile Valley (Egypt): lithostratigraphy, biostratigraphy, mineralogy and geochemistry. Neues Jahrbuch für Geologie und Paläontologie-Abhandlungen, v. 258 , pp. $1-30$.

Speijer, R. P., 2000. The late Paleocene event and a potential precursor compared: First results from Egypt. GFF, v. 122, pp. 150-151.

Speijer, R. P., 2003. Danian-Selandian sea-level change and biotic excursion on the southern Tethyan margin (Egypt). In: Wing, S.L., Gingerich, P.D., Schmitz, B. and Thomas E. (Eds.). Causes and Consequences of Globally Warm Climates in the Early Paleogene. Boulder, Colorado. Geological Society of America Special Paper, v. 369 , pp. $275-290$.

Speijer, R. P. and Schmitz, B., 1998. A benthic foraminiferal record of Paleocene sea-level changes and trophic conditions at Gebel Aweina, Egypt. Palaeogeography, Palaeoclimatology, Palaeoecology, v. 137, pp. 79-101.

Sprong, J., Speijer, R. P. and Steurbaut, E., 2009. Biostratigraphy of the Danian/Selandian transition in the southern Tethys. Special reference to the Lowest Occurrence of planktic foraminifera Igorina albeari. Geologica Acta, v. 7, pp. 63-77.

Steurbaut, E., 1998. High-resolution holostratigraphy of Middle Paleocene to Early Eocene strata of Belgium and adjacent areas. Palaeontographica, Abt. A, v. 247, 5-6, pp. 91-156, Stuttgart. 
Steurbaut, E. and Sztrákos K., 2008. Danian/Selandian boundary criteria and North Sea Basin - Tethys correlations based on calcareous nannofossil and foraminiferal trends in SW France. Marine Micropaleontology, v. 67, pp. 1-29.

Steurbaut, E., Dupuis, C., Arenillas, I., Molina, E. and Matmati, M.F., 2000. The Kalaat Senan section in central Tunisia: A potential reference section for the Danian/Selandian boundary. GFF, v. 122, pp. 158-160.

Ten Kate, W. G. and Sprenger A., 1993. Orbital cyclicities above and below the Cretaceous/Paleogene boundary at Zumaya (N Spain), Agost and Relleu (SE Spain). Sedimentary Geology, v. 87, pp. 69-101.

Thomas, E., 2005. Benthic foraminifera and Early Eocene hyperthermal events (SE Atlantic Ocean). Geological Society of America, Abstracts with Programs, 37(7):413.

Thomsen, E., 1994. Calcareous nannofossil stratigraphy across the Danian/Selandian boundary in Denmark. GFF, v. 116, pp. 65-67.

Thomsen, E. and Heilmann-Clausen, C., 1985. The Danian/Selandian boundary at Svejstrup with remarks on the biostratigraphy of the boundary in western Denmark. Bulletin of the Geological Society of Denmark, v. 33, pp. 341-362.

Van Itterbeeck, J., Sprong, J., Dupuis, C., Speijer, R.P. and Steurbaut, E., 2007. Danian/Selandian boundary stratigraphy and ostracod records from Sidi Nasseur, Tunisia. Marine Micropaleontology, v. 62, pp. 211-234.

Van Vliet, A., 1982. Submarine fans and associated deposits in the lower Tertiary of Guipúzcoa (northern Spain). Ph. D. thesis, Lanbouwhogeschool Wageningen, $45 \mathrm{p}$.

Varadi, F., Runnegar, B. and Ghil, M., 2003. Successive refinements in long-term integrations of planetary orbits. Astrophysical Journal, v. 592, pp. 620-630.

Varol, O., 1989. Palaeocene calcareous nannofossil biostratigraphy. In: Crux, J.A. and van Heck, S.E. (Eds.). Nannofossils and their Applications. British Micropaleontological Society, v. 12, pp. 267310.

Ward, P. and Kennedy, K. G., 1993. Maastrichtian ammonites from the Biscay region (France, Spain). Journal of Paleontology, v. 67, pp. 1-58.

Westerhold, T., Röhl, U., Raffi, I., Fornaciari, E., Monechi, S., Reale, V., Bowles, J. and Evans, H. F., 2008. Astronomical calibration of the Paleocene time. Palaeogeography, Palaeoclimatology, Palaeoecology, v. 257, pp. 377-403.

Westerhold, T., Röhl, U., Donner, B., McCarren, H. K. and Zachos, J. C., 2011. A complete high-resolution Paleocene benthic stable isotope record for the central Pacific (ODP Site 1209). Paleoceanography, no. PA2216. DOI: 10.1029/2010PA002092.

White, N. J., Lowell, B., 1997. Measuring the pulse of a plume with the sedimentary record. Nature, v. 387, pp. 888-891.

Wiedmann, J., 1986. Macro-invertebrates and the Cretaceous/Tertiary boundary. In: Walliser, O. (Ed.). Global Bio-Events. Lecture Notes in Earth Sciences, v. 8, pp. 397-409.

Zachos, J. C., Kroon, D. and 25 others, 2004. Early Cenozoic extreme climates: The Walvis Ridge transect. Proceedings of the Ocean Drilling Program, Leg 208, http://www-odp.tamu/edu/ publications/208-IR/208ir.htm.

Ziegler, P. A., 1990. Geological Atlas of Western Europe and Central Europe. 2nd Edition. Shell Internationale Petroleum Maatschappij, B.V., Den Haag, 239 pp.

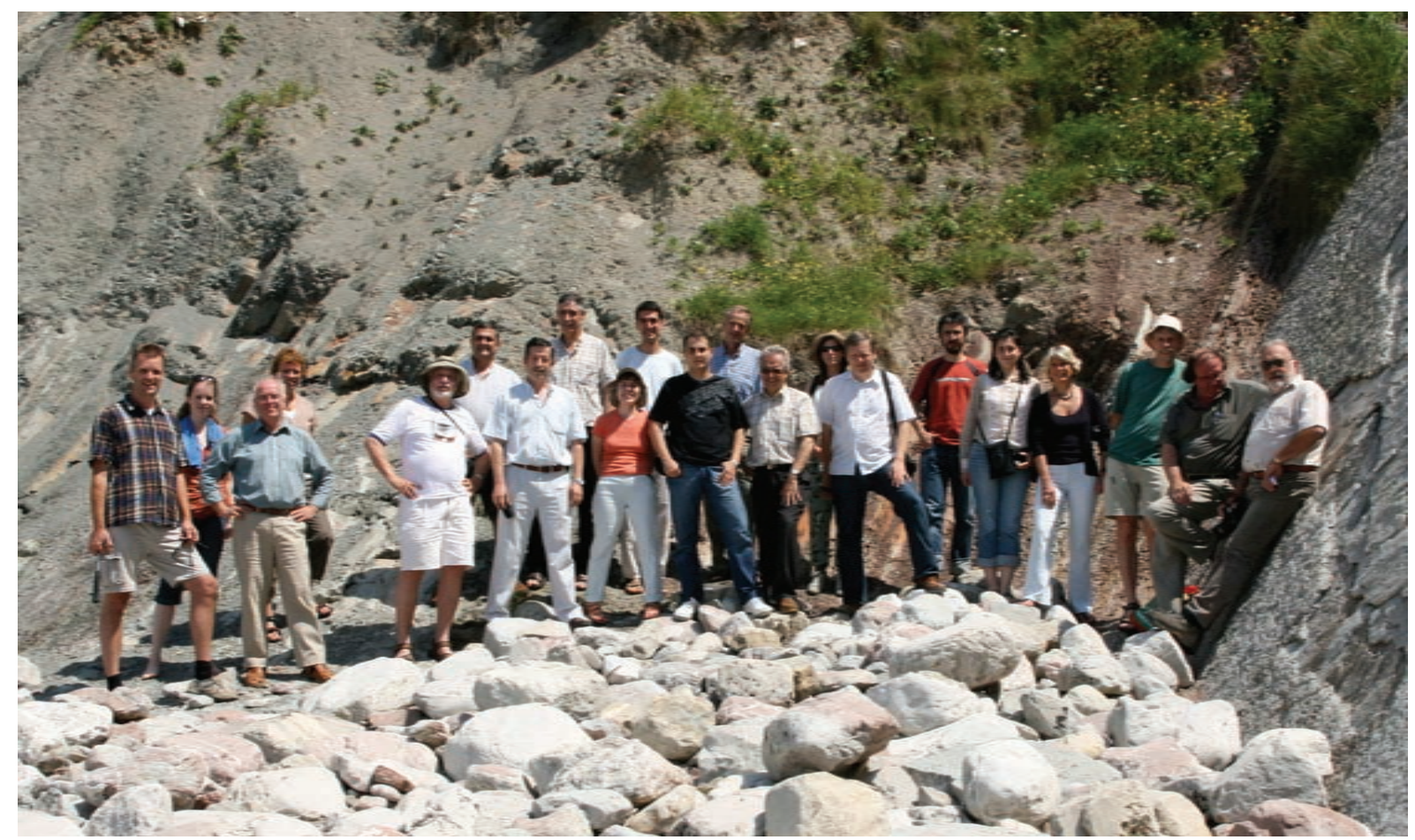

Members of the Paleocene Working Group in front of the basal Selandian outcrop at Itzurun Beach, June 2007. From left to right: Robert Speijer, Jorinde Sprong, Erik Thomsen, Anne Clemmensen, Bill Berggren, Fernando Caballero, Eustoquio Molina, Xabier Orue-Etxebarria, Maria Rose Petrizzo, Aitor Payros, Ignacio Arenillas, Robert Knox, Victoriano Pujalte, Marie-Pierre Aubry, Birger Schmitz, Gilen Bernaola, Maite Martín-Rubio, Simonetta Monechi, Claus Heilmann-Clausen, Etienne Steurbaut, and Christian Dupuis. Members not shown in photo are: Laia Alegret, Estibaliz Apellaniz, Juan-Ignacio Baceta, Jaume Dinarès-Turell, Asier Hilario Orús, Silvia Ortiz and Katharina von Salis. 